\title{
The Composition of Cigarette Smoke. An Historical Perspective of Several Polycyclic Aromatic Hydrocarbons*
}

\author{
by \\ Alan Rodgman ${ }^{1}$ and Lawrence C. Cook ${ }^{2}$ \\ ${ }^{1} 2828$ Birchwood Drive, Winston-Salem, North Carolina, 27103-3410, USA \\ ${ }^{2}$ Brighton Gardens of Winston-Salem, Sunrise Senior Living, 2601 Reynolda Road, Apartment 234 \\ Winston-Salem, North Carolina, 27106, USA
}

\section{SUMMARY}

Because of the significant advancements in fractionation, analytical, and characterization technologies since the early 1960s, hundreds of components of complex mixtures have been accurately characterized without the necessity of actually isolating the individual component. This has been particularly true in the case of the complex mixtures tobacco and tobacco smoke. Herein, an historical account of a mid-1950 situation concerning polycyclic aromatic hydrocarbons (PAHs) in cigarette smoke is presented. While the number of PAHs identified in tobacco smoke has escalated from the initial PAH, azulene, identified in 1947 to almost 100 PAHs identified by late 1963 to more than 500 PAHs identified by the late 1970 s, the number of PAHs isolated individually and characterized by several of the socalled classical chemical means (melting point, mixture melting point, derivative preparation and properties) in the mid-1950s and since is relatively few, 14 in all. They were among 44 PAHs identified in cigarette mainstream smoke and included the following PAHs ranging from bicyclic to pentacyclic: Acenaphthylene, 1,2-dihydroacenaphthylene, anthracene, benz $[a]$ anthracene, benzo $[a]$ pyrene, chrysene, dibenz $[a, h]$ anthracene, fluoranthene, $9 H$-fluorene, naphthalene, 1-methylnaphthalene, 2-methylnaphthalene, phenanthrene, and pyrene. One of them, benzo $[a]$ pyrene, was similarly characterized in another study in 1959 by HofFMANN. [Beitr. Tabakforsch. Int. 23 (2009) 384-410]

\section{ZUSAMENFASSUNG}

Wegen bedeutender Fortschritte bei der Fraktionierung, der Analytik und der Charakterisierung von Substanzen seit den frühen 1960iger Jahren wurden Hunderte von Verbindungen komplexer Gemische präzise charakterisiert, ohne dass die Notwendigkeit bestand einzelne Substanzen zu isolieren. Dies gilt in besonderem Maße für die komplexen Gemische Tabak und Tabakrauch. Diese Arbeit beschreibt in einem historischen Rückblick den Wissenstand zu den polyzyklischen aromatischen Kohlenwasserstoffe (PAHs) im Zigarettenrauch in der Mitte der 1950iger Jahre. Während die Anzahl der im Tabakrauch identifizierten PAHs vom zuerst bekannten Azulene, das 1947 identifiziert wurde auf fast 100 PAHs am Ende des Jahres 1963 und mehr als 500 PAHs am Ende der 1970iger Jahre stark anwuchs, ist die Anzahl der individuell analysierten und durch die Methoden der sogenannten klassischen Chemie charakterisierten (Schmelzpunkt, Siedepunkt, Derivate und deren Eigenschaften) seit der Mitte der 1950iger Jahre bis heute relative gering, insgesamt 14. Diese PAHs befinden sich unter den 44 PAHs, die sich im Hauptstromrauch von Zigaretten befinden und umfassten die nachfolgenden bizyklischen bis pentazyklischen PAHs: Acenaphthylen, 1,2-Dihydroacenaphthylen, Anthracen, Benz $[a]$ anthracen, Benzo $[a]$ pyren, Chrysen, Dibenz $[a, h]$ anthracen, Fluoranthen, $9 H$-Fluoren, Naphthalin, 1-Methylnaphthalin, 2-Methylnaphthalin, Phenanthren und Pyren. Eine dieser Substanzen, und zwar Benzo $[a]$ pyren, wurde außerdem in einer anderen Arbeit im Jahre 1959 von HOFFMANN charakterisiert. [Beitr. Tabakforsch. Int. 23 (2009) 384-410] 


\section{RESUME}

A cause des progrès significatif dans les technologies de fractionnement, d'analyse et de caractérisation depuis le début des années 1960, des centaines de composants de mélanges complexes ont été caractérisés de façon précise sans pour autant devoir isoler le composent individuel. Ceci a particulièrement été le cas pour les mélanges complexes du tabac et de la fumée de tabac. Cet étude présente la situation des hydrocarbures polynucléaires aromatiques (PAH) dans la fumée de cigarettes au milieu des années 1950. Tandis que le nombre des PAHs identifiés dans la fumée de tabac a rapidement augmenté, du PAH initial, l'azulène, identifié en 1947, à presque 100 PAHs identifiés à la fin de l'année 1963, pour arriver à plus de 500 PAHs identifiés à la fin de l'année 1970, le nombre des PAHs isolés individuellement et caractérisés par plusieurs des moyens chimiques appelés classiques (point de fusion, point de fusion du mélange, propriétés et préparation de dérivés) au milieu des années 1950 et depuis cette epoche, est resté relativement bas, 14 en tout. Ceux-ci sont parmi les 44 PAHs identifiés dans la fumée principale de cigarette et comprennent les PAHs suivants, allant des PAHs bicycliques aux PAHs pentacycliques. acenaphthylène, 1,2dihydroacénaphthylène, anthracène, benz $[a]$ anthracène, benzo $[a]$ pyrène, chrysène, dibenz $[a, h]$ anthracène, fluoranthène, $9 H$-fluorène, naphthalène, 1-methylnaphthalène, 2-methylnaphthalène, phenanthrène, and pyrène. Un des PAHs a parallèlement été caractérisé en 1959 dans une autre étude par HofFMANN. [Beitr. Tabakforsch. Int. 23 (2009) 384-410]

\section{INTRODUCTION}

Over fifty years ago, by use of the so-called classical chemistry method, 14 polycyclic aromatic hydrocarbons (PAHs) were isolated from the cigarette smoke condensate (CSC) of a commercial cigarette. Twelve of the 14 PAHs were isolated in crystalline form and two as oils. Although complete R.J. Reynolds Tobacco Company (RJRT) in-house reports describing the research $(1,2,3)$ are available on the Internet ${ }^{a}$ and a summary of the research was included in a recent publication (4), the complete details of it have never been published.

Between the early 1950s and the mid-1960s, numerous reports were published on the identification of PAHS in tobacco smoke, particularly cigarette smoke. In most of the pre-1957 studies, the evidence presented for the identification of a particular PAH consisted solely of ultraviolet (UV) absorption spectral data. The early claims to the identification of benzo $[a]$ pyrene $(\mathrm{B}[a] \mathrm{P})$ in cigarette smoke $(5,6,7)$, based on UV spectral data, were criticized by other investigators because of a) their inability to duplicate the reported experiments by use of similar techniques (8) or b) because of the incompleteness of the UV spectral data (9). However,

\footnotetext{
${ }^{a}$ While the date on the in-house RODGMAN-COOK report (3) is mid1960 , the isolation/identification research on the 44 PAHs was actually completed between mid-1956 and early 1958. The delay in finalizing the report was due to personnel involvement in a detailed study of the effect of organic solvent extraction of tobacco on the yield of various PAHs in cigarette mainstream smoke.
}

subsequent study (10) or assessment of more recent data (11) by the critics subsequently resulted in reversal of their original opinion.

Since 1957, numerous technologies have been used to isolate and identify trace amounts of certain PAHs in tobacco smoke. These include: Fluorescence spectrometry, paper chromatography, thin-layer and vapor-phase chromatography, isotope dilution, liquid-liquid partition, and mass spectrometry. The advantages and disadvantages of many of these technologies were discussed at length by WYNDER and HOFFMANN in their 1964 review (12) and 1967 book (13) on tobacco and tobacco smoke. In 1959, WYNDER and HOFFMANN reported the isolation of $\mathrm{B}[a] \mathrm{P}$ in crystalline form from CSC and the establishment of its identity by evidence other than UV spectral data, namely, by melting point comparison and mixture melting point data with an authentic $\mathrm{B}[a] \mathrm{P}$ sample (14). Because the study described herein was conducted in the mid-1950s but never published as such, the similar criteria used to identify PAHs isolated in crystalline or oil form from CSC might be of some historical interest to the reader.

To maintain chronological perspective, most references utilized in the discussion on PAHs herein will precede the issuance of the 1964 smoking-health report of the Advisory Committee to the U.S. Surgeon General (15). At that time, 97 PAHs had been identified in CSC, 18 of which were noted specifically by the Advisory Committee, 61 by Philip Morris in its 1963 monograph on tobacco and tobacco smoke components (16) (provided in 1963 to the Advisory Committee), and 77 by R.J. Reynolds $(1,2,17)$ in various research reports [see Table 2 in RoDGMAN (4)]. In a manuscript submitted for publication in late 1963 and published in early 1964 [shortly after release of the Advisory Committee report (15)], ELMENHORST and RECKZEH (18) catalogued 89 aromatic hydrocarbons identified in tobacco smoke. Of the 89, 77 were PAHs, the other 12 were monocyclic aromatic hydrocarbons identified in tobacco smoke. Obviously, the Advisory Committee did not have access to this manuscript prior to the publication of its report to the U.S. Surgeon General. However, it is an indication that the author of the tobacco and tobacco smoke chapter in the 1964 Advisory Committee was much less meticulous in collecting published tobacco smoke PAH data than were ELMENHORST and RECKZEH.

With the advent of many new fractionation and analytical technologies and particularly their excellent utilization by SNOOK et al. (19) at the U.S. Department of Agriculture (USDA), the number of PAHs identified in CSC underwent a more than five-fold increase between late 1963 and the late 1970s [see Table 6 in Rodgman and Perfetti (20)].

The fractionation-isolation procedure used in this mid-1950 CSC PAH study at RJRT Research Department was one originally designed in the early 1950 s by one of us (A.R.) for a research study conducted at the Banting and Best Department of Medical Research at the University of Toronto, Toronto, Ontario, Canada on an industrial tar, one generated during an industrial process in a major U.S. industry. Two existing technologies were combined: a) The ability of PAHs to form complexes with picric acid, the technology used in the early 1930 s by COOK et al. (21) in their isolation and identification of several PAHs, including $\mathrm{B}[a] \mathrm{P}$ and benzo[e]pyrene $(\mathrm{B}[\mathrm{e}] \mathrm{P})$, from coal tar. b) The 
decomposition of the PAH:picric acid complexes during column chromatography on alumina and the successive elution of the PAHs by solvents such as pentane or hexane. In the first isolation study of PAHs from CSC, picric acid was used as the complexing agent. For a second, more extensive study, the well-known PAH complexing agent 2,4,7-trinitrofluorenone (TNF) (22) was substituted for the picric acid.

Two early studies on the identification of PAHs in mainstream CSC were conducted at RJRT, the first beginning in late 1954. The initial RJRT PAH investigation involved isolation and identification of 11 PAHs in the mainstream CSC from 10500 commercial non-filtered 70$\mathrm{mm}$ cigarettes (1). Of the $11 \mathrm{PAHs}$, five were isolated in crystalline form (see Table 1). The cigarettes were smoked in a system modeled after that described by WYNDER et al. in their generation of cigarette tar for their study of its carcinogenicity (23). Instead of the smoking procedure described in 1936 by BRADFORD et al. (24), i.e., 35-mL puff, 2-sec puff duration, one puff/min, the smoking of the cigarettes paralleled that described by WYNDER et al. (23), i.e., $35-\mathrm{mL}$ puff, 2 -sec puff duration, three puff/min. The butt length for non-filtered cigarettes was $20-25 \mathrm{~mm}$; that for filtered cigarettes was the $17 \mathrm{~mm}$ of the filter tip plus 3-4 $\mathrm{mm}$ of the tobacco rod. This was done in order to generate a comparison between our PAH data with the biological data reported by WYNDER et al. (23). Certain fractions of this CSC were fractionated to isolate and characterize unequivocally by classical chemical methods some of the PAHs in the CSC. The isolation procedure involved the following sequence: Liquid-liquid partition, repeated column chromatography on alumina to obtain a PAH-rich fraction, treatment of the PAH-rich fraction with TNF to form PAH:TNF complexes, separation of the complexes from extraneous aliphatic hydrocarbons and other long-chained neutral components, decomposition of the PAH:TNF complexes on alumina to concentrate the PAHs, and repeated chromatography of the PAH mixture to yield individual PAHs.

Five PAHs - naphthalene, anthracene, pyrene, fluoranthene, and $\mathrm{B}[a] \mathrm{P}$ - were isolated in crystalline form and characterized by UV spectral data as well as by the usual classical chemical means mentioned previously. The remaining six PAHs (phenanthrene, acenaphthylene, 2methylpyrene, 1,2-benz $[a]$ anthracene $(\mathrm{B}[a] \mathrm{A})$, benzo[ghi]perylene, and dibenzo[def,mno]chrysene) were identified on the basis of agreement of their UV absorption spectra with those of authentic samples and/or with published UV spectral data.

The second investigation involved the mainstream CSC from 20000 commercial filter-tipped cigarettes (2). Identified were 44 PAHs ${ }^{\mathrm{b}}$, including the $11 \mathrm{PAHs}$ identified in the initial study (1). Of the 44 PAHs, 12 were isolated in crystalline form [acenaphthylene, 1,2-dihydroacenaphthylene, anthracene, $\mathrm{B}[a] \mathrm{A}, \mathrm{B}[a] \mathrm{P}$, chrysene, dibenz $[a, h]$ anthracene $(\mathrm{DB}[a, h] \mathrm{A})$, fluoranthene, $9 H$ -

\footnotetext{
${ }^{\mathrm{b}}$ In a summary in a previous publication (4), the number of PAHs reported was 43 instead of 44: 14 characterized by various aspects of classical chemistry, 29 characterized by UV absorption spectra. Inadvertently omitted from that manuscript was the identification of the PAH benz $[e]$ acephenanthrylene (benzo[b]fluoranthene).
}

fluorene, naphthalene, phenanthrene, pyrene] and two as oils (1-methyl- and 2-methylnaphthalene) and all 14 were characterized not only by UV spectral data but also by other classical chemical means. Table 1 summarizes the characterization criteria used for these 14 PAHs plus estimates of their yields under the smoking conditions used in this study. The other 30 PAHs were identified primarily from the agreement of their UV absorption spectra with those of authentic samples or with published spectra (Table 2). $\mathrm{B}[a] \mathrm{P}, \mathrm{B}[a] \mathrm{A}$, and $\mathrm{DB}[a, h] \mathrm{A}$ had been reported to be tumorigenic to mouse skin $(25,26)$ although the bioassay data on the tumorigenicity of $\mathrm{B}[a] \mathrm{A}$ were contradictory. Several years after completion of the second study, two notable situations arose in which 1,2-dihydrobenz[j]aceanthrylene (cholanthrene) and dibenzo[def,p]chrysene (formerly named dibenzo[a,l]pyrene, initially 1,2,3,4dibenzopyrene or 3,4,8,9-dibenzopyrene) were involved. The changes over time in nomenclature for 660 PAHs are summarized in the 1997 National Institute of Standards and Technology publication authored by SANDERS and WISE (27). The original RODGMAN-COOK identifications of these two PAHs, based solely on UV spectral data, were later found to be incorrect. From UV spectral data that were not totally in agreement with those of an authentic sample, RODGMAN and COOK (3) incorrectly defined one of them as the PAH 1,2-dihydrobenz[j]aceanthrylene (cholanthrene). In the massive study by SNOOK et al. at the USDA on the identification of PAHs in cigarette smoke, 1,2-dihydrobenz[j]aceanthrylene was not among the several benzocyclopentanthracenes identified (19). As a result, the listing of 1,2-dihydrobenz[j] aceanthrylene (cholanthrene) has been changed from its original listing to benzocyclopentanthracene. The other incorrectly characterized PAH was dibenzo[def,p]chrysene. For its identification as a tobacco smoke component, not only RODGMAN and COOK (3) but also Rodgman (2), BonNeT and NEUKOMm (28), LYONS and JOHNSTON (29), LYONS (30), WYNDER and WRIGHT (31), and PYRIKI (32) relied on available UV spectral data, purportedly those of synthetic dibenzo[def,p]chrysene (dibenzo[a,l]pyrene). However, in 1966, LAVIT-LAMY and BUU-HOÏ (33) determined that the published UV spectral data were not those of dibenzo[a,l]pyrene but of its isomer dibenz $[a, e]$ aceanthrylene (dibenzo[a,e]fluoranthene), generated during the supposed synthesis of dibenzo[def,p]chrysene (dibenzo[a,l]pyrene). As a result of the finding of LAVIT-LAMY and BUU-HoÏ, the entry of dibenzo[def,p]chrysene (dibenzo[ $a, l]$ pyrene) has been changed from its original listing to dibenz $[a, e]$ aceanthrylene.

\section{EXPERIMENTAL}

All solvents employed in the chemical fractionation and column chromatography of the CSC fractions were optically transparent insofar as PAHs were concerned. The chromatographic adsorbents used were Aluminum Oxide Merck (Merck Cat. No. 71707) and Fluorisil ${ }^{\circledR}(60-100$ mesh) from the Floridin Company, Tallahassee, FL. All melting and mixed melting points were determined with a Fisher-Johns melting point apparatus. UV absorption spectra were determined at $25^{\circ} \mathrm{C}$ with a Beckman DK-2 


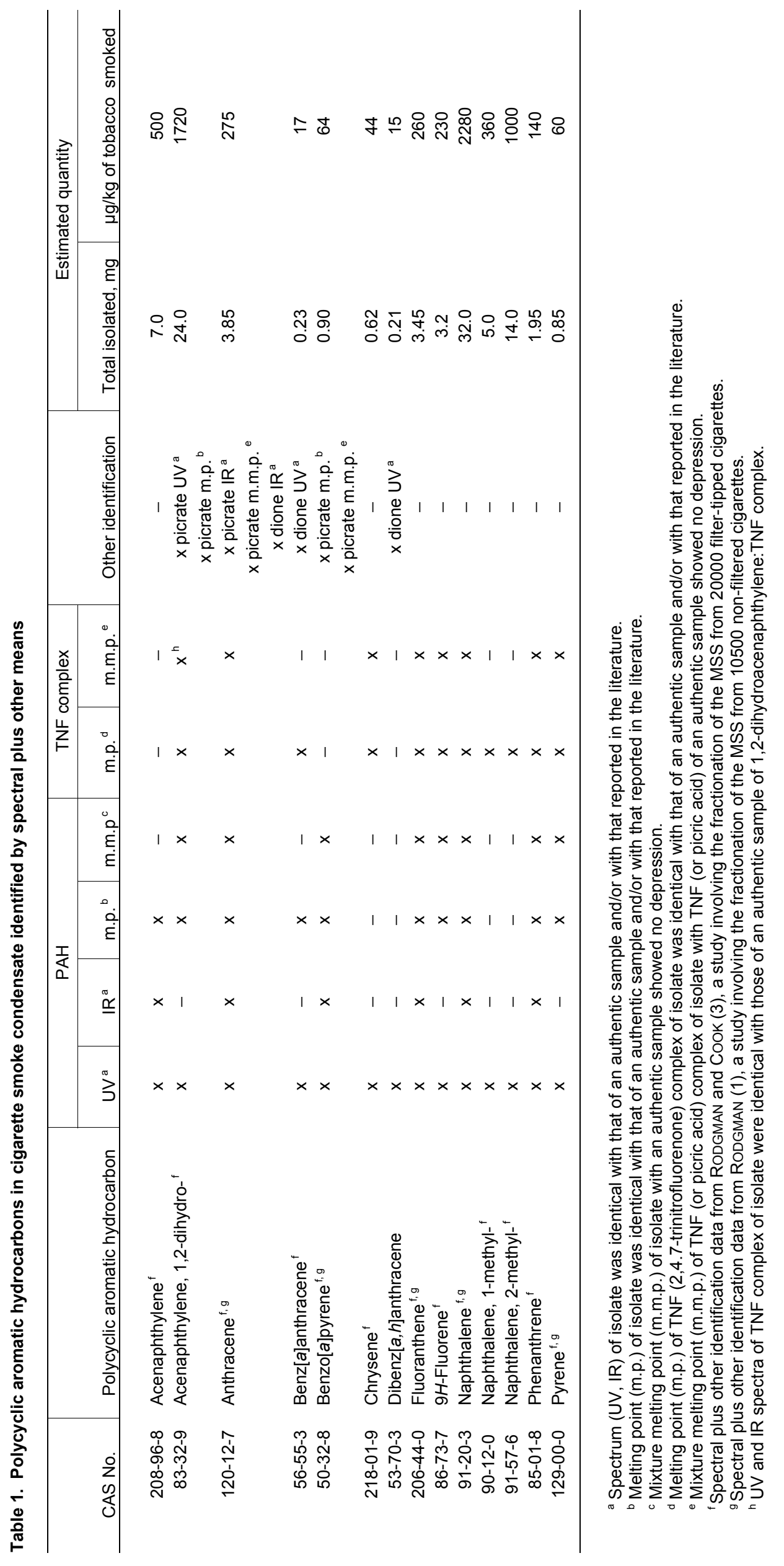


Table 2. Polycyclic aromatic hydrocarbons from cigarette smoke condensate characterized by ultraviolet absorption spectra only

\begin{tabular}{|c|c|c|c|}
\hline \multirow[b]{2}{*}{ CAS No. } & \multirow[b]{2}{*}{ Polycyclic aromatic hydrocarbon } & \multicolumn{2}{|c|}{ Estimated quantity } \\
\hline & & Total isolated, mg & $\mu \mathrm{g} / \mathrm{kg}$ of tobacco smoked \\
\hline $779-02-2$ & Anthracene, 9-methyl- & 0.60 & 43 \\
\hline $205-99-2$ & Benz[e]acephenanthrylene & 0.63 & 44 \\
\hline 2319-96-2 & Benz[a]anthracene, 5-methyl- & 0.05 & 3 \\
\hline & Benzocyclopentanthracene $\mathrm{a}^{\mathrm{a}}$ & 0.09 & 6 \\
\hline $7099-43-6$ & 1H-Benzo[a]cyclopent[h]anthracene, 2,3-dihydro- & $\sim 0.01$ & trace \\
\hline $7099-42-5$ & 9H-Benzo[a]cyclopent[I]anthracene, 10,11-dihydro- & $\sim 0.01$ & trace \\
\hline $203-12-3$ & Benzo[ghi]fluoranthene & 0.03 & trace \\
\hline $205-82-3$ & Benzo[]]fluoranthene & $\sim 0.01$ & trace \\
\hline $207-08-9$ & Benzo $[k]$ fluoranthene & $\sim 0.01$ & trace \\
\hline $189-55-9$ & Benzo[rst]pentaphene & 0.02 & trace \\
\hline $191-24-2$ & Benzo[ghi]perylene & 0.24 & 17 \\
\hline $195-19-7$ & Benzo[c]phenanthrene & & \\
\hline 25167-89-9 & Benzo[a]pyrene, methyl- & 0.08 & 6 \\
\hline 192-97-2 & Benzo[e]pyrene & 0.62 & 44 \\
\hline $41637-90-5$ & Chrysene, methyl- & 0.30 & 22 \\
\hline $191-07-1$ & Coronene & 0.05 & 3 \\
\hline $5385-75-1$ & Dibenz[a,e]aceanthrylene ${ }^{b}$ & 0.02 & trace \\
\hline $189-64-0$ & Dibenzo[b,def]chrysene & $\sim 0.01$ & trace \\
\hline $191-26-4$ & Dibenzo[def,mno]chrysene & 0.10 & 7 \\
\hline $193-09-9$ & Dibenzo[de,qr]naphthacene & 0.02 & trace \\
\hline $30997-39-8$ & Fluoranthene, methyl- & 0.60 & 43 \\
\hline $4373-13-1$ & Naphthalene, 1,2-dihydro-4-methyl- & 3.5 & 250 \\
\hline $612-94-2$ & Naphthalene, 2-phenyl- & 2.0 & 140 \\
\hline $196-42-9$ & Naphtho[2,1,8-qra]naphthacene & 0.02 & trace \\
\hline $198-55-0$ & Perylene & 0.20 & 14 \\
\hline $29062-98-4$ & Phenanthrene, dimethyl- & 2.0 & 140 \\
\hline $883-20-5$ & Phenanthrene, 9-methyl- & 0.85 & 60 \\
\hline $2381-21-7$ & Pyrene, 1-methyl- & 0.87 & 62 \\
\hline $3442-78-2$ & Pyrene, 2-methyl- & 0.05 & 3 \\
\hline $3353-12-6$ & Pyrene, 4-methyl- & 0.72 & 51 \\
\hline
\end{tabular}

\footnotetext{
a Originally, because of the similarity but not total agreement of the UV spectrum of this PAH with that of 1,2-dihydrobenz[j]aceanthrylene (cholanthrene), RODGMAN and COOK (3) designated this PAH as 1,2-dihydrobenz[j]aceanthrylene (cholanthrene). The major reason for the change in designation was the following: Although numerous benzocyclopentanthracenes were identified in CSC by SNOOK et al. (19), none was designated as 1,2-dihydrobenz[j]aceanthrylene (cholanthrene).

b Dibenz[a,e]aceanthrylene, sometimes known as dibenz[a,e]fluoranthene, was originally classified as dibenzo[def,p]chrysene (dibenzo[a,I]pyrene, 1,2,3,4-dibenzopyrene, 3.4.8.9-dibenzopyrene) in several CSC studies (2, 28, 29, 30, 31, 32) but the PAH originally designated as dibenzo[a,/]pyrene from a synthesis was subsequently found by LAVIT-LAMY and BUU-HOÏ (33) to be its isomer, dibenz[a,e]aceanthrylene.
}

Ratio Recording Spectrometer, 10-mm silica cells, and PAH-free absolute ethanol or cyclohexane as solvent. Infrared (IR) absorption spectra were determined by John J. Whalen with a Perkin-Elmer Model 21 Spectrophotometer.

\section{Smoking procedure}

The 20000 cigarettes smoked and the smoking procedure were described in detail by RODGMAN and COOK (34). The weight of the tobacco smoked was $14.0 \mathrm{~kg}$.

\section{Neutral-acidic fraction}

The collection of the hexane-soluble neutral-acidic fraction (248 g) and its preliminary chromatography on alumina to yield a hexane-eluted fraction (38.6 g), a 4:1 hexane:benzene-eluted fraction $(19.1 \mathrm{~g})$, and a methanol-eluted fraction (113 g) were described previously (34).

\section{Chromatography of the hexane-eluted fraction}

The hexane-eluted fraction (38.6 g) was chromatographed in 9- to 10 -g lots on alumina $[45 \mathrm{~mm}($ diam $) \times 125 \mathrm{~mm}$ column] initially with hexane $(100 \mathrm{~mL})$ to remove the bulk of the saturated aliphatic hydrocarbons and neophytadiene (35). The next $175 \mathrm{~mL}$ of hexane yielded a non-fluorescent eluate (UV light exposure) which contained the squalenes and solanesenes (36). Hexane $(8 \times 100 \mathrm{~mL})$ and methanol $(5 \times 100 \mathrm{~mL})$ elution yielded highly fluorescent eluates of 0.6 to $0.8 \mathrm{~g}$ for each of the four chromatograms, totaling 3.2 g. This material when combined with the $4: 1$ hexane:benzene-eluted fraction $(19.1 \mathrm{~g})$ yielded $22.3 \mathrm{~g}$ of oil, highly fluorescent to UV light.

\section{Complex formation with 2,4,7-trinitrofluorenone (TNF)}

The fluorescent oil $(22.2 \mathrm{~g})$ in $25 \mathrm{~mL}$ of benzene at $60^{\circ}$ was treated with a solution of TNF $(7.5 \mathrm{~g})$ in glacial acetic acid $(180 \mathrm{~mL})$ [cf. (22)]. After heating the resulting solution to the boiling point, then allowing it to cool to $25{ }^{\circ} \mathrm{C}$, a reddish- 
brown precipitate formed. The suspension was concentrated to dryness, diluted with hexane $(200 \mathrm{~mL})$, agitated for $0.5 \mathrm{~h}$, and filtered to remove hexane-soluble long-chained compounds which did not complex with TNF. The residue, consisting of TNF:PAH complexes plus unreacted TNF, was washed with hexane $(150 \mathrm{~mL})$, filtered, and dried. Concentration of the filtrate and washings yielded an oil (20.4 g). Chromatography of a 1.0-g aliquant yielded no fraction with the characteristic blue fluorescence of the PAHs. Treatment of a similar aliquant with TNF $(0.35 \mathrm{~g})$ gave no indication of TNF:PAH complex formation.

\section{Chromatography of the TNF:PAH complex mixture}

The TNF:PAH complex mixture was decomposed by chromatography on alumina $[75 \mathrm{~mm}($ diam $) \times 100 \mathrm{~mm}$ column] (22). The mixture was added to the column in $1: 1$ benzene:chloroform $(150 \mathrm{~mL})$ and the PAHs eluted with 8 $\mathrm{L}$ of $4: 1$ hexane:benzene. Concentration yielded $0.748 \mathrm{~g}$ of a PAH mixture which exhibited an intense-blue-green fluorescence in UV light. Per $\mathrm{kg}$ of tobacco smoke, the PAH mixture represented about $53 \mathrm{mg}$ of PAHs.

The PAH mixture in $1: 1$ benzene:hexane $(30 \mathrm{~mL})$ on alumina $[25 \mathrm{~mm}(\text { diam }) \times 600 \mathrm{~cm} \text { column }]^{\mathrm{c}}$ was eluted by $325100-\mathrm{mL}$ solvent treatments. After development of the column, exposure to UV light indicated 17 distinct and separate fluorescent zones, ranging from pale blue to blueviolet in color. In many instances, diffuse fluorescent zones were present between the more distinctly fluorescent zones. Table 3 lists the eluting solvents used plus the approximate constitution of the fractions obtained. The constitution of some PAHs could not be determined from their UV absorption. As a result, they were not included in Table 3. Each fraction collected was concentrated, dissolved in absolute ethanol or cyclohexane, and its UV absorption spectrum determined. Based on UV absorption similarities, certain fractions were combined (see Table 3 ) and rechromatographed on alumina to separate the suspected PAHs. Some over-laps were inevitable between the various combined subgroups but they are not shown in Table 3.

To preserve remaining PAH fractions while a particular fraction was being investigated, the combined fractions containing particular groups of PAHs were treated with excess TNF in benzene or ethanol, concentrated to dryness, and the resulting TNF:PAH complex mixture stored in the dark. Subsequent decomposition of the TNF:PAH complexes on alumina permitted recovery of the $\mathrm{PAH}(\mathrm{s})$ for further study.

\section{Polycyclic aromatic hydrocarbons}

The quantities of the various PAHs found in this study are minimal values. The identity of each of the various PAHs was based on one or more of the following: UV absorption ${ }^{\mathrm{d}}$, IR absorption, melting point (m.p.) and/or mixture melting

\footnotetext{
${ }^{\mathrm{c}}$ To conduct the chromatography, this $6.0-\mathrm{m}$ column (assembled from three shorter Pyrex tubes by SHAFFNER) was set up in a stair well and carefully packed with the alumina.

${ }^{\mathrm{d}}$ In RODGMAN and COOK (2), 44 Figures are depicted in which miniaturized versions of the UV absorption spectra of the various $\mathrm{PAH}$ isolates are compared with those of authentic PAH samples plus miniaturized versions of the UV absorption spectra of the several diones are compared to those of authentic samples.
}

points (m.m.p.) of the isolate and of a derivative [PAH:picric acid complex, TNF:PAH complex, quinone (dione)].

1) 1-Methyl-3,4-dihydronaphthalene (CAS No. 4373-13-1): This PAH was tentatively identified on the basis of its UV absorption spectrum. It was essentially the same as that subsequently reported by FRIEDEL and ORCHIN (37). The amount isolated was estimated to be $3.5 \mathrm{mg}$.

2) Naphthalene (CAS No. 91-20-3): Chromatography (alumina) of the naphthalene-rich fraction yielded $28 \mathrm{mg}$ of crystalline naphthalene, m.p. $78-80^{\circ} \mathrm{C}$. The m.m.p. with an authentic sample, m.p. $80.5-81.0{ }^{\circ} \mathrm{C}$, gave no depression. Its UV absorption spectrum maxima were at 257, 267, 277, 287, and $311 \mathrm{~m} \mu$. The UV and IR spectra were identical with those of authentic naphthalene. Treatment with TNF yielded the naphthalene:TNF complex, m.p. $151-155{ }^{\circ} \mathrm{C}$ [reported 151.2-154.0 ${ }^{\circ} \mathrm{C}(22)$ ]. The m.m.p. with an authentic sample prepared as described by ORCHIN et al. (22) showed no depression. The IR spectra of the TNF:isolate complex and TNF:naphthalene complex were identical.

3) 1-Methylnaphthalene (CAS No. 90-12-0): The 1methylnaphthalene-rich fractions on chromatography (alumina) yielded an additional $4 \mathrm{mg}$ of crystalline naphthalene (total $=32 \mathrm{mg}$ ) and $3.8 \mathrm{mg}$ of the colorless oil 1-methylnaphthalene. The UV spectrum of the isolate (maxima at 271, 282, 292, $313 \mathrm{m \mu}$ ) was identical with that of an authentic sample. Treatment with TNF yielded the 1methylnaphthalene:TNF complex, m.p. $161-162{ }^{\circ} \mathrm{C}$ [reported $\left.163.4-164.8{ }^{\circ} \mathrm{C}(38,39)\right]$. M.m.p. with an authentic sample $(38,39)$ gave no depression.

4) 2-Methylnaphthalene (CAS No. 91-57-6): The 2methylnaphthalene-rich fractions on chromatography (alumina) yielded an additional $1.2 \mathrm{mg}$ of 1-methylnaphthalene (total $=5.0 \mathrm{mg}$ ) and $14 \mathrm{mg}$ of 2-methylnaphthalene as colorless oils. The UV spectrum of the latter isolate was identical with that of an authentic sample. Treatment with TNF yielded the orange crystalline 2methylnaphthalene:TNF complex, m.p. $122-124{ }^{\circ} \mathrm{C}$ [reported 124.6-126.0 ${ }^{\circ} \mathrm{C}$ (22]. M.m.p. with an authentic sample (22) gave no depression. The 2-methylnaphthalene:TNF complex was a 1:2 complex as described earlier $(38,39)$. The quantities of naphthalene, 1-methyl- and 2methylnaphthalene isolated from the CSC were minimal values since these PAHs were particularly prone to sublimation (naphthalene) or distillation (the methyl derivatives).

5) 2-Phenylnaphthalene (CAS No. 612-94-2): Examination of the UV absorption spectra of several fractions following those containing phenanthrene indicated the presence of a PAH suspected to be 2-phenylphenanthrene because of the absorption maxima at 250 and $287 \mathrm{~m} \mu$ (37).

6) Acenaphthylene, 1,2-dihydro- (acenaphthene) (CAS No. 83-32-9): Chromatography (alumina) of the acenaphthylene- and 1,2-dihydroacenaphthylene-rich fractions yielded $24 \mathrm{mg}$ of crystalline 1,2-dihydroacenaphthylene, m.p. 94.0-95.0 ${ }^{\circ}$ C. M.m.p. with an authentic sample gave no depression. Treatment with TNF yielded bright red needles, m.p. $169-175^{\circ} \mathrm{C}$. Recrystallization raised the m.p. to $174.5-176.0{ }^{\circ} \mathrm{C}$. M.m.p. with authentic 1,2-dihydroacenaphthylene:TNF [m.p. $175{ }^{\circ} \mathrm{C}$ (22)] gave no depression. Treatment of the isolated $\mathrm{PAH}$ with picric acid 
Table 3. Column chromatography of the polycyclic aromatic hydrocarbon mixture

\begin{tabular}{|c|c|c|c|}
\hline Fraction No. & Eluting solvent & $\begin{array}{l}\text { Fractions } \\
\text { combined }\end{array}$ & Components \\
\hline $1-75$ & hexane & $\begin{array}{r}2-3 \\
4-7 \\
8-13 \\
14-18 \\
19-22 \\
23-30 \\
31-34 \\
35-41 \\
42-52 \\
53-60 \\
61-75\end{array}$ & $\begin{array}{l}\text { naphthalene; 1,2-dihydro-4-methylnaphthalene; } \\
\text { 1-methylnaphthalene; 2-methylnaphthalene; } \\
\text { 2-phenylnaphthalene; acenaphthylene; } \\
\text { 1,2-dihydroacenaphthylene; } 9 \mathrm{H} \text {-fluorene; phenanthrene; } \\
\text { dimethylphenanthrene; } \\
\text { 9-methylphenanthrene }\end{array}$ \\
\hline $\begin{array}{l}76-85 \\
86-95 \\
96-105 \\
106-115\end{array}$ & $\begin{array}{l}2 \% \text { benzene-hexane } \\
5 \% \text { benzene-hexane } \\
8 \% \text { benzene-hexane } \\
10 \% \text { benzene-hexane }\end{array}$ & $\begin{array}{r}76-84 \\
85-90 \\
91-96 \\
97-105 \\
106-117\end{array}$ & $\begin{array}{l}\text { anthracene; 9-methylanthracene; pyrene; 1-methylpyrene; } \\
\text { 2-methylpyrene; 4-methylpyrene; fluoranthene }\end{array}$ \\
\hline $\begin{array}{l}116-125 \\
126-135\end{array}$ & $\begin{array}{l}13 \% \text { benzene-hexane } \\
16 \% \text { benzene-hexane }\end{array}$ & $\begin{array}{l}118-126 \\
127-134\end{array}$ & fluoranthene, methylfluoranthene \\
\hline $\begin{array}{l}136-145 \\
146-165\end{array}$ & $\begin{array}{l}20 \% \text { benzene-hexane } \\
25 \% \text { benzene-hexane }\end{array}$ & $\begin{array}{l}135-145 \\
146-150 \\
151-158 \\
159-153\end{array}$ & $\begin{array}{l}\text { benzo[c]phenanthrene; } \\
\text { benzo[ghi]fluoranthene; } \\
\text { benzo[j]fluoranthene; benzo[k]fluoranthene; benz }[e] \text { acephenanthrylene }\end{array}$ \\
\hline $166-245$ & $35 \%$ benzene-hexane & $\begin{array}{l}164-172 \\
173-179 \\
180-193 \\
194-197 \\
198-201 \\
201-210 \\
211-231 \\
232-246\end{array}$ & $\begin{array}{l}\text { benz[a]anthracene; } 5 \text {-methylbenz[a]anthracene; } \\
\text { 2,3-dihydro- } 1 \mathrm{H} \text {-benzo[a]cyclopent }[h] \text { anthracene; } \\
\text { 10,11-dihydro- } 9 H \text {-benzo[a]cyclopent[]]anthracene; } \\
\text { chrysene; methylchrysenes; perylene; } \\
\text { benzo[a]pyrene; methylbenzo[a]pyrene; } \\
\text { benzo[e]pyrene; benzo[ghi]perylene }\end{array}$ \\
\hline $\begin{array}{l}246-255 \\
256-265 \\
266-285 \\
286-295\end{array}$ & $\begin{array}{l}45 \% \text { benzene-hexane } \\
50 \% \text { benzene-hexane } \\
60 \% \text { benzene-hexane } \\
80 \% \text { benzene-hexane }\end{array}$ & $\begin{array}{l}247-252 \\
253-272 \\
273-288 \\
289-295\end{array}$ & $\begin{array}{l}\text { benzo[ghi]perylene; benzocyclopentanthracene; } \\
\text { dibenz }[a, h] \text { anthracene }\end{array}$ \\
\hline 296-305 & benzene & $\begin{array}{r}296-303- \\
304-305\end{array}$ & dibenz $[a, h]$ anthracene \\
\hline $\begin{array}{l}306-315 \\
316-325\end{array}$ & $\begin{array}{l}\text { ethyl acetate } \\
\text { methanol }\end{array}$ & $\begin{array}{l}306-311 \\
312-318 \\
319-321 \\
322-325\end{array}$ & $\begin{array}{l}\text { dibenzo[de,qr]naphthacene; naphtho[2,1,8-qra]naphthacene } \\
\text { dibenzo[b,def]chrysene; dibenzo[def,mno]chrysene; } \\
\text { dibenz[a,e]aceanthrylene; benzo[rst]pentaphene; coronene }\end{array}$ \\
\hline
\end{tabular}

in 1:1 ethanol:water, followed by crystallization from benzene, yielded 1,2-dihydroacenaphthylene:picric acid complex as orange needles, m.p. $159-160^{\circ} \mathrm{C}$ [reported m.p. $\left.160-161{ }^{\circ} \mathrm{C}(40)\right]$. The UV (maxima at 279, 290, 300, 306, $321 \mathrm{~m} \mu$ ) and IR spectra of the isolate and the IR spectrum of the 1,2-dihydroacenaphthylene:TNF complex were identical with those of authentic samples of the PAH and its TNF complex.

7) Acenaphthylene (CAS No. 208-96-8): The acenaphthylene-rich fractions from the chromatograms described above were combined and rechromatographed (alumina) to yield $7.0 \mathrm{mg}$ of colorless, crystalline hydrocarbon, m.p. $90-91{ }^{\circ} \mathrm{C}$, which on recrystallization melted at $91.5-92.0^{\circ} \mathrm{C}$. The UV (maxima at 266, 324, $339 \mathrm{m \mu}$ ) and IR spectra of the isolate were identical with those of authentic acenaphthylene, m.p.
91-92 ${ }^{\circ} \mathrm{C}$, prepared by lead oxide oxidation of 1,2 dihydroacenaphthylene. M.m.p. of the isolate with authentic acenaphthylene gave no depression.

8) $9 H$-Fluorene (CAS No. 86-73-7): The $9 H$-fluorene-rich fractions were successively chromatographed (alumina) three times to yield $3.2 \mathrm{mg}$ of a colorless, crystalline solid, m.p. $113.5-114.5^{\circ} \mathrm{C}$. Its UV spectrum (maxima at $263,289,300$ $\mathrm{m} \mu$ ) was identical with that of authentic $9 H$-fluorene. M.m.p. of the isolate and authentic acenaphthylene, m.p. 115.5-116.5 ${ }^{\circ} \mathrm{C}$, gave no depression. Treatment with TNF yielded a crystalline isolate:TNF complex, m.p. $176-177^{\circ} \mathrm{C}$. M.m.p. of the isolate:TNF complex with authentic $9 H$ fluorene:TNF complex, m.p. $179.0-179.5^{\circ} \mathrm{C}$, prepared by the method of ORCHIN et al. (22), gave no depression, m.p. $177.5-179.0{ }^{\circ} \mathrm{C}$. 
9) Phenanthrene (CAS No. 85-01-8): The phenanthrenerich fractions were chromatographed (alumina) to yield a colorless, crystalline solid, m.p. $97-98^{\circ} \mathrm{C}$. UV (maxima at 252, 274, 281, $293 \mathrm{m \mu}$ ) and IR absorption studies indicated the presence of $1.95 \mathrm{mg}$ of PAH with spectra identical with that of authentic phenanthrene. A m.m.p. study with authentic phenanthrene, m.p. $99.0-99.5^{\circ} \mathrm{C}$, gave a m.p. $98-99{ }^{\circ} \mathrm{C}$. Treatment of the isolate with TNF gave a complex, m.p. $194-196{ }^{\circ} \mathrm{C}$, which gave no depression on admixture with an authentic sample, m.p. $196-197{ }^{\circ} \mathrm{C}$, of phenanthrene:TNF prepared by the method of ORCHIN et al. (22).

10) 9-Methylphenanthrene (CAS No. 883-20-5): Fractions following the phenanthrene fractions had UV absorption spectra very similar to that of 9-methylphenanthrene (maxima at 256, 278, 285, $297 \mathrm{m \mu}$ ). The yield was estimated as $0.6 \mathrm{mg}$.

11) Dimethylphenanthrene (CAS No. 29062-98-4): Fractions following the phenanthrene and 9-methyl homolog fractions appeared to contain other phenanthrene homologs. Their UV absorption spectra were similar to those of dimethylphenanthrenes but not all of the maxima or minima matched those of the 1,2-, 1,3-, 1,7-, 1,8-, 1,9-, 2,3-, 2,5-, 4,5-, or 4,9-dimethylphenanthrenes. The yield was estimated as $2.0 \mathrm{mg}$.

12) Anthracene (CAS No. 120-12-7): The anthracene-rich fractions were repeatedly chromatographed (alumina) to yield $3.85 \mathrm{mg}$ of crystalline anthracene, m.p. $210-212^{\circ} \mathrm{C}$. M.m.p. with authentic anthracene, m.p. $215-216^{\circ} \mathrm{C}$, gave no depression. Treatment with TNF gave anthracene:TNF complex, m.p. $190-193{ }^{\circ} \mathrm{C}$, as deep red needles. Crystallization from ethanol raised the m.p. to $193.0-194.5^{\circ} \mathrm{C}$ [m.p. reported as $\left.193.8-194.0{ }^{\circ} \mathrm{C}(22)\right]$. M.m.p. with authentic anthracene:TNF complex, m.p. $193.1-193.8^{\circ} \mathrm{C}$, prepared as described by ORCHIN et al. (22), gave no depression. The UV (maxima at 252, 309, 323, 338, 356, $376 \mathrm{m \mu}$ ) and IR absorption spectra were identical with those of authentic anthracene.

13) 9-Methylanthracene (CAS No. 779-02-2): Chromatography (alumina) of the fractions following the anthracene fractions gave fractions with UV absorption (maxima at $302,315,332,348,367,387 \mathrm{~m} \mu$ ) identical with that of 9methylanthracene. Several of the later factions in the sequence indicated contamination with traces of pyrene as indicated by UV absorption at $333 \mathrm{~m} \mu$.

14) Pyrene (CAS No. 129-00-0): Repeated chromatography (alumina) of the pyrene-rich fractions yielded $0.85 \mathrm{mg}$ of a colorless, crystalline solid, m.p. $148-150{ }^{\circ} \mathrm{C}$ (reported 149-150 ${ }^{\circ} \mathrm{C}$ ) with UV absorption (maxima at 230, 241, $251,263,272,292,305,318,333,352,356,362,372 \mathrm{m \mu})$ identical with that of authentic pyrene. Treatment of the isolate with TNF yielded pyrene:TNF complex as red needles, m.p. 239-241 ${ }^{\circ}$ C. M.m.p. with an authentic pyrene:TNF complex sample (22), m.p. $241.5-242.5^{\circ} \mathrm{C}$, gave no depression.

15) 1-Methylpyrene (CAS No. 2381-21-7): The 1-, 3-, and 4-methylpyrenes were obtained by repeated chromatography (alumina) of the fractions following the pyrene fractions. The UV absorption $(272,308,321,337 \mathrm{~m} \mu)$ for one isolate was identical with that of authentic 1methylpyrene, weight $0.85 \mathrm{mg}$.

16) 2-Methylpyrene (CAS No. 3442-78-2): UV absorption maxima at 294, 313, 328, 343, $353 \mathrm{m \mu}$ ) indicated $50 \mu \mathrm{g}$ of 2-methylpyrene. Several other chromatographic fractions (alumina) indicated a mixture of 1- or 4-methylpyrene and 2-methylpyrene but repeated column chromatography did not result in further separation.

17) 4-Methylpyrene (CAS No. 3353-12-6): As indicated by agreement of the UV absorption spectrum (maxima at 273, $296,307,318,336 \mathrm{m \mu}$ ) of the isolate with that of authentic 4-methylpyrene, $0.72 \mathrm{mg}$ of 4-methylpyrene was isolated. 18) Fluoranthene (CAS No. 206-44-0): Repeated chromatography (alumina) of the fluoranthene-rich fractions yielded crystalline fluoranthene, m.p. 106.5-108.5 ${ }^{\circ} \mathrm{C}$ (reported $110.0-110.5{ }^{\circ} \mathrm{C}$ ). M.m.p. with authentic fluoranthene gave no depression. UV absorption studies (absolute ethanol, maxima at 245, 253, 262, 272, $276,283,288,309,323,342,359 \mathrm{m \mu}$ ) indicated $3.45 \mathrm{mg}$. The IR absorption of the isolate was identical with that of authentic fluoranthene. Treatment with TNF yielded the orange crystalline fluoranthene:TNF complex, m.p.. 205-207 ${ }^{\circ} \mathrm{C}$. Crystallization from ethanol raised the m.p. to 210-212 ${ }^{\circ} \mathrm{C}$ (reported $215-216^{\circ} \mathrm{C}$ ). M.m.p. with authentic fluoranthene :TNF complex (22), m.p. $215-216^{\circ} \mathrm{C}$, gave no depression.

19) Methylfluoranthene (CAS No. 30997-39-8): Methylfluoranthene, possibly more than one, was isolated from the fractions following the fluoranthene fractions. Identification was based on the similarities between UV absorption spectra of the isolate and that of fluoranthene and the shift of the maxima to slightly longer wavelengths. Based on UV absorption, the amount of methylfluoranthene was estimated at $0.60 \mathrm{mg}$.

20) Benzo $[c]$ phenanthrene (CAS No. 195-19-7): Trace amounts (approximately $10 \mu \mathrm{g}$ ) of spectrally pure benzo $[c]$ phenanthrene were obtained chromatographically (alumina). UV absorption maxima were observed at 280, $314,327,254$, and $371 \mathrm{~m} \mu$ in agreement with those of an authentic sample. Several other fractions appeared to contain additional traces of benzo[c]phenanthrene but no attempt was made to estimate the amount.

21) Benzo[ghi]fluoranthene (CAS No. 203-12-3): A very small quantity (approximately $30 \mu \mathrm{g}$ ) of spectrally pure benzo[ghi]fluoranthene was obtained with UV absorption maxima at 280, 290, 321, 349, 381, and $402 \mathrm{m \mu}$.

22) Benzo[j]fluoranthene (CAS No. 205-82-3): Trace amounts (approximately $10 \mu \mathrm{g}$ ) of benzo[j]fluoranthene were obtained by chromatography (alumina). UV absorption maxima were noted at 282, 293, 308, 317, 331, $347,364,375$, and $383 \mathrm{~m} \mu$, identical with those of an authentic sample.

23) Benzo $[k]$ fluoranthene (CAS No. 207-08-9): Trace amounts (approximately $10 \mu \mathrm{g}$ ) of benzo[ $k]$ fluoranthene were obtained by chromatography (alumina). UV absorption maxima were recorded at 296, 308, 358, 378, and $401 \mathrm{~m} \mu$. The following problem is often encountered in a situation involving separation of components of a subfraction of a complex mixture: Several fractions were obtained with UV absorption maxima indicative of possible mixtures of benz[e]acephenanthrylene, benzo[j]fluoranthene, benzo $[k]$ fluoranthene, and/or benzo[ghi]fluoranthene but no attempt was made to estimate the amounts of these PAHs in the fractions. Several attempts to separate them chromatographically (alumina) were unsuccessful. 
24) Benz[e]acephenanthrylene (CAS No. 205-99-2): Benz $[e]$ acephenanthrylene (estimated amount, $0.63 \mathrm{mg}$ ) was obtained by chromatography (alumina). UV absorption maxima at 240, 257. 278, 291, 295, 302, 340, 352, and 370 $\mathrm{m} \mu$ agreed with those of an authentic sample.

25) Benz $[a]$ anthracene (B $[a] \mathrm{A})(\mathrm{CAS}$ No. 56-55-3): B[a]Arich fractions were repeatedly chromatographed (alumina) to yield an isolate with UV absorption maxima at 254, 267, 280, 290, 299, 316, 329, 344, 359, 366, 375, and $384 \mathrm{m \mu}$. The maxima were identical with those of an authentic sample of $\mathrm{B}[a] \mathrm{A}$. Its amount was estimated at $227 \mu \mathrm{g}$. The sample size did not permit too precise a m.p. determination, softening at $150{ }^{\circ} \mathrm{C}$, m.p. $154-155^{\circ} \mathrm{C}$. Treatment with TNF gave a red solid, m.p. $220-222^{\circ} \mathrm{C}$ [reported $223-224^{\circ} \mathrm{C}$ for $\mathrm{B}[a] \mathrm{A}: \mathrm{TNF}$ (22)]. Decomposition of the B[a]A:TNF complex on alumina, oxidation of the PAH with $3.0 \mathrm{mg}$ of chromic acid in $1.0 \mathrm{~mL}$ of acetic acid, dilution with water $(20 \mathrm{~mL})$, followed by extraction with benzene $(5 \mathrm{~mL})$ yielded a compound whose UV absorption spectrum was identical with that of $\mathrm{B}[a] \mathrm{A}-7,12$-dione.

26) 5-Methylbenz $[a]$ anthracene (CAS No. 2319-96-2): A PAH with a UV absorption spectrum essentially the same as that of 5-methylbenz $[a]$ anthracene was isolated (maxima at 280, 291, 300, 327, 340, 357, 367, $388 \mathrm{m \mu}$ ). Its amount was estimated at $50 \mu \mathrm{g}$.

27) 2,3-Dihydro- $1 H$-benzo $[a]$ cyclopent $[h]$ anthracene (CAS No. 7099-43-6) and 28). 10,11-Dihydro-9H-benzo[ $a]$ cyclopent $i$ ] anthracene (CAS No. 7099-42-5): Fractions contained isolates with UV absorption maxima which agreed with those of 2,3-dihydro- $1 H$-benzo[ $a]$ cyclopent $[h]$ anthracene $(282,293,321,336,352,370,388 \mathrm{m \mu})$ and 10,11dihydro-9H-benzo $[a]$ cyclopent $[i]$ anthracene $(280,297,302$, $316,320,438,360,387 \mathrm{m \mu})(42)$. Trace amounts (about 10 $\mu \mathrm{g})$ of each of these PAHs were obtained but some background UV absorption shifted the maxima slightly to longer wavelengths but not enough for the change to be interpreted as due to the presence of a methyl group.

29) Chrysene (CAS No. 218-01-9): Repeated chromatography (alumina) of the chrysene-rich fractions yielded several fractions with absorption maxima at 268, 284, 295, $307,319,344,353$, and $363 \mathrm{~m} \mu$, in agreement with those observed for authentic chrysene. The crystalline material melted at $249-251{ }^{\circ} \mathrm{C}$. Treatment wit TNF yielded the chrysene:TNF complex, yellow needles, m.p. 246-248 ${ }^{\circ} \mathrm{C}$ [reported m.p. $\left.247.8-249.0{ }^{\circ} \mathrm{C}(22)\right]$. It was estimated that $0.62 \mathrm{mg}$ of chrysene was present. Several other fractions obviously contained chrysene admixed with chrysene-like compounds, possibly one or more methylchrysenes.

30). Methylchrysenes (CAS No. 41637-90-5): Rechromatography of the chrysene-methylchrysenes fraction yielded approximately $0.3 \mathrm{mg}$ of methylchrysenes with UV absorption maxima at 269, 297, 313, 328, 348, and $366 \mathrm{m \mu}$. These UV maxima did not exactly match those recorded for 1-methylchrysene, 4-methylchrysene, 5-methylchrysene, or 6-methylchrysene. A mixture of them was proposed.

31) Perylene (CAS No. 198-55-0): Repeated chromatography (alumina) of the perylene-rich fractions yielded approximately $0.2 \mathrm{mg}$ of spectrally pure perylene with UV absorption maxima $(244,252,263,343,367,388,408,434$ $\mathrm{m} \mu$ ) that agreed with those of an authentic sample. It was estimated that an additional $0.1 \mathrm{mg}$ of perylene was present in fractions preceding and subsequent to those fractions containing the spectrally pure perylene.

32) Benzo $[a]$ pyrene $(\mathrm{B}[a] \mathrm{P})(\mathrm{CAS}$ No. 50-32-8): The $\mathrm{B}[a] \mathrm{P}$ rich fractions were chromatographed (alumina) repeatedly to yield $0.905 \mathrm{mg}$ of $\mathrm{B}[a] \mathrm{P}, \mathrm{m} . \mathrm{p} .178-180{ }^{\circ} \mathrm{C}$, m.m.p. with authentic $\mathrm{B}[a] \mathrm{P}$, m.p. $180-181{ }^{\circ} \mathrm{C}$, gave no depression. The UV absorption spectrum (maxima at 267, 273, 286, 297, 333, $348,364,380,386,403 \mathrm{~m} \mu$ ) was identical at each maximum and each minimum with the UV absorption spectrum of an authentic sample of $\mathrm{B}[a]$ P. M.m.p. of the isolate:picric acid and authentic $\mathrm{B}[a] \mathrm{P}$ :picric acid complexes, prepared as described by FIESER (41), gave no depression.

33) Methylbenzo[a]pyrene (CAS No. 25167-89-9): A sample $(80 \mu \mathrm{g})$ of a PAH was obtained by repeated chromatography (alumina) with a UV absorption spectrum almost identical with that of $\mathrm{B}[a] \mathrm{P}$, except each maximum was shifted to a slightly longer wavelength. This suggested a methyl- $\mathrm{B}[a] \mathrm{P}$. 34) Benzo[e]pyrene (B[e]P) (CAS No. 192-97-2): Repeated chromatography (alumina) of the $\mathrm{B}[e] \mathrm{P}$-rich fractions yielded $0.62 \mathrm{mg}$ of $\mathrm{B}[e] \mathrm{P}$ with UV absorption maxima $(278,289$, $304,318,322,348,358,367 \mathrm{m \mu}$ ) identical with those of an authentic sample.

35) Benzo[ghi]perylene (CAS No. 191-24-2): BY repeated chromatography (alumina), benzo[ghi]perylene $(0.24 \mathrm{mg})$ was obtained with UV absorption maxima at 291, 303, 331, $348,367,388,406 \mathrm{~m} \mu$. UV absorption spectra indicated that several minor isolated fractions were mixtures of $\mathrm{B}[a] \mathrm{P}$ and benzo[ghi]perylene.

36) Benzocyclopentanthracene: A small quantity (90 $\mu \mathrm{g})$ of a benzocyclopentanthracene was obtained by repeated chromatography (alumina) of benzocyclopentanthracene-rich fractions. UV absorption maxima were obtained at 284, 296, $328,342,358,376$, and $390 \mathrm{~m} \mu$, most of which agreed with those of an authentic sample of the PAH 1,2dihydrobenz[j]aceanthrylene (cholanthrene). Attempts to prepare a PAH:TNF complex suitable for a m.p. determination were unsuccessful because of the sample size. However, an olive-green color characteristic of 1,2dihydrobenz[j]aceanthrylene:TNF complex was obtained by treatment of the PAH with one equivalent of TNF in an ethanol-benzene solution. As noted previously, the absence of this PAH from the many PAHs identified by SNOOK et al. (19) indicated that our original assignment was erroneous. 37) Dibenz $[a, h]$ anthracene (DB $[a, h] \mathrm{A})$ (CAS No. 53-70-3): The $\mathrm{DB}[a, h] \mathrm{A}$-rich fractions were repeatedly chromatographed (alumina) with hexane-benzene solutions as eluents. The amount of DB $[a, h] \mathrm{A}$ was estimated at $0.205 \mathrm{mg}$, based on calculation from its UV absorption spectrum. Treatment of the $\mathrm{DB}[a, h] \mathrm{A}$ with $3 \mathrm{mg}$ of chromic oxide in $1.5 \mathrm{~mL}$ of glacial acetic acid yielded $0.225 \mathrm{mg}$ of $\mathrm{DB}[a, h] \mathrm{A}-7,12$-dione, based on calculation from its UV absorption spectrum. Thus the oxidation gave a $90 \%$ yield. UV absorption maxima ( 230 , $278,290,301,323,337,351,373,386,396 \mathrm{m \mu}$ ) for the $\mathrm{DB}[a, h] \mathrm{A}$ isolate and absorption maxima $(297,334,390 \mathrm{~m} \mu)$ for the $\mathrm{DB}[a, h] \mathrm{A}-7,12$-dione were determined in absolute ethanol.

These agreed with UV absorption maxima obtained with authentic sample of $\mathrm{DB}[a, h] \mathrm{A}$ and $\mathrm{DB}[a, h] \mathrm{A}-7,12$-dione, respectively. The IR absorption spectrum of the dione, while not too definitive, did agree substantially with that of an authentic sample.

38) Dibenzo[de,qr]naphthacene (CAS No. 193-09-9) and 39) Naphtho[2,1,8-qra]naphthacene (CAS No. 196-42-9): The 
reported UV absorption maxima for dibenzo[de,qr]naphthacene were $297,309,321,328,345,367,375,386,396$, and $408 \mathrm{~m} \mu$ whereas those reported for naphtho[2,1,8qra]naphthacene were 247, 286, 297, 320, 335, 385, 406, and $458 \mathrm{m \mu}$ (42). A PAH sample was obtained for which all of the above-listed maxima were present $(247,286,297,309$, $320,328,335,345,367,375,385,396,407,430,458 \mathrm{m \mu})$. It was concluded that both PAHs were present in the sample. 40) Dibenzo[b,def]chrysene (CAS No. 189-64-0): Repeated chromatography (alumina) yielded a trace amount (about 10 $\mu \mathrm{g})$ of dibenzo[ $[b, d e f]$ chrysene with UV absorption maxima $(290,302,314,379,401,425,452 \mathrm{~m} \mu)$ identical with those of an authentic sample

41) Dibenzo[def,mno]chrysene (CAS No. 191-26-4): About $100 \mu \mathrm{g}$ of spectrally pure dibenzo[def,mno]chrysene were obtained by repeated chromatography (alumina) of the dibenzo[def,mno]chrysene-rich fractions. UV absorption maxima $(260,297,309,385,408,437 \mathrm{~m} \mu)$ of the isolate agreed with those obtained with an authentic sample. Some overlapping was noted between several fractions containing dibenzo[def,mno]chrysene and other PAHs of unknown structure.

42) Dibenz $[a, e]$ aceanthrylene $^{\mathrm{e}}$ (CAS No. 5385-75-1): Repeated chromatography (alumina, then Fluorisil $($ ) yielded a trace amount (about $20 \mu \mathrm{g}$ ) of spectrally pure dibenz $[a, e]$ aceanthrylene (dibenz $[a, e]$ fluoranthene) with UV absorption maxima at 291, 305, 319, 332, 352, 363, 374, 403, and $438 \mathrm{~m} \mu$.

43) Benzo[rst $]$ pentaphene (CAS No. 189-55-9): Repeated chromatography (alumina) yielded a trace amount (about $20 \mu \mathrm{g}$ ) of dibenzo[rst]pentaphene with UV absorption maxima $(274,284,297,316,330,354,375,395,419 \mathrm{m \mu})$ identical with those of an authentic sample. UV absorption analyses of several other fractions indicated they contained mixtures of dibenzo[b,def $]$ chrysene, benzo $[r s t]$ pentaphene, and dibenzo[def,mno]chrysene but no clear-cut separation could be effected by repeated column chromatography.

44) Coronene (CAS No. 191-07-1): Approximately $50 \mu \mathrm{g}$ of coronene were isolated. Its UV absorption spectrum showed maxima at 328, 338, 342 and $388 \mathrm{~m} \mu$.

UV absorption spectra devoid of background absorption were obtained for many fractions obtained from the lengthy chromatogram. Even though these showed spectral characteristics typical of PAHs, no structural assignments could be made for any of the suspected PAHs despite diligent examination of much UV absorption data catalogued in the literature by FRIEDEL and ORCHIN (37), CLAR (42), and others. It was suspected that many mixtures of PAHs were obtained and that such mixtures contained PAHs already identified in this study plus PAHs that could not be identified.

\section{DISCUSSION}

The fact that over 40 PAHs were identified in this study and about 50 were identified in other pre-1964 studies by more or

\footnotetext{
${ }^{\mathrm{e}}$ For many years, dibenz $[a, e]$ aceanthrylene (also known occasionally as dibenzo[a,e]fluoranthene) was catalogued as dibenzo[def,p]chrysene (known chronologically as 1,2,3,4-dibenzopyrene or 3,4,8,9dibenzopyrene and then dibenzo[ $a, l]$ pyrene) but a 1966 study by LAVITLAMY and BUU-HOÏ (33) defined the compound originally thought to be dibenzo $[a, l]$ pyrene as its isomer dibenz $[a, e]$ aceanthrylene.
}

less classical chemical means indicates the limitations of the technologies involved in the so-called classical chemical technology. The first PAH identified in tobacco smoke was azulene in 1947 by IKEDA (43). However, earlier in the late 1930s-early 1940s, ROFFO and his son had reported the identification of anthracene, phenanthrene, and $\mathrm{B}[a] \mathrm{P}$ in the destructive distillate of tobacco $(44,45)$. Their findings were much discounted by various authorities who insisted that a destructive distillate of tobacco had no relationship to tobacco smoke [see p. 259 in WYNDER and HOFFMANN (12), p. 94 in WYNDER and HOFFMANN (13), pp. 422-424 in LARSON et al. (46)]. Many of the findings reported by ROFFO on the chemical and biological properties of the destructive distillate of tobacco and on the destructive distillate of organic solvent-extracted tobacco parallel the qualitative but not quantitative properties subsequently reported on CSC from control and organic solvent-extracted tobaccos (47). Several situations subsequently stimulated substantial interest in the possibility of the presence of PAHs in cigarette smoke:

- The publication in the early 1950 s of the results obtained in a series of epidemiological studies, each of which indicated the adverse effect of cigarette smoking on the incidence of lung cancer in cigarette smokers (48).

- The 1953 report by WYNDER et al. (23) of the induction of skin carcinomas in a significant percentage of laboratory animals (mice) skin painted repeatedly for many months with concentrated solutions of cigarette "tar."

- The number of reports listed by HARTWELL in his 1951 survey of tumorigenic compounds (25) on tumor induction in laboratory animals skin painted or injected subcutaneously with solutions of various individual PAHs. The biological results obtained with more than 270 PAHs were summarized by HARTWELL. Examination of his tabulation reveals that 99 of the PAHs and their alkyl derivatives tested (36.5\%) exhibited tumorigenicity. Very few bicyclic or tricyclic PAHs were reported as tumorigenic. For the total of 232 tetracyclic, pentacyclic, and hexacyclic PAHs and their alkyl derivatives listed by HARTWELL (25), the number reported as tumorigens was $96(41.4 \%)$.

As a result of the increased effort to study PAHs in cigarette smoke, the number of identified PAHs in cigarette smoke had increased to almost 100 by late 1963 . Over the next decade and a half with the incredible advancements in fractionation and analytical technologies and their utilization in the characterization of the components of complex mixtures such as cigarette smoke, the number of identified PAHs in cigarette smoke was increased more than five-fold from the fewer than 100 to more than 500 [see research outline by SNOOK et al. (19), PAH catalogue by RODGMAN and PERFETTI (20)]. An additional factor is that many of the later characterizations by SNOOK et al. (19) were accomplished by smoking far fewer cigarettes than the 20000 cigarettes smoked in the RODGMAN-COOK study (3) to obtain sufficient CSC for fractionation and study of the PAH-rich fractions by classical chemical means. While a plethora of different types of spectral and graphical data (UV, IR, NMR, and mass spectra plus gas chromatograms) have been used to identify literally 
hundreds of the PAHs in cigarette smoke, the number isolated in crystalline form or as oils has remained relatively few, totaling less than $3 \%$ of the more than 500 PAHs identified in cigarette smoke.

The more recent use of advanced analytical technologies and the generation of much meaningful spectral and graphical data rather than the earlier classical chemical methods as the basis for the identification of literally hundreds of the chemical components in tobacco and tobacco smoke is not being criticized. Examination of the procedures used by SNOOK et al. in their studies of PAHs (19) and aza-arenes (49) in tobacco smoke, those used by NEWELL et al. (50), SCHUMACHER et al. (51), and HECKMAN and BEST (52) in their studies on cigarette smoke composition ${ }^{\mathrm{f}}$, and those used by LLOYD et al. (53), LefFingwell and Alford (54), and PeNG et al. (55) in their studies on tobacco composition indicates the great number of chemical components unequivocally identified as well as the paucity of identification errors.

Table 4 summarizes many of the references on the chronological identification of the 97 PAHs identified in tobacco smoke prior to the 1964 publication of the famous Advisory Committee's report to the U.S. Surgeon General (15). Of the 97 PAHs listed, 91 had been described in nearly 200 pre-1964 publications. Surprisingly, in the chapter on tobacco and tobacco smoke composition [Chapter 6 in (15)], the Advisory Committee member (FIESER) and his consultant (ORCHIN) who authored the chapter discussed in detail 18 named PAHs. Of the 18, 13 named $\mathrm{PAHs}^{\mathrm{g}}$ were described as cigarette smoke components (acenaphthylene, 1,2-dihydroacenaphthylene, anthracene, $\mathrm{B}[a] \mathrm{A}$, benzo[j]fluoranthene, benzo[rst]-pentaphene, benzo[ghi]perylene, benzo $[c]$ phenanthrene, $\mathrm{B}[a] \mathrm{P}$, $\mathrm{DB}[a, h] \mathrm{A}$, dibenzo[def,p]chrysene, fluorene, phenanthrene, pyrene) but the five other named PAHs were discussed as being present as components of carbon black (benzo[ghi]perylene, benzo[e]pyrene, coronene, dibenzo[def,mno]chrysene, fluoranthene). Several of the 13 named PAHs had reported tumorigenic properties. Although none was mentioned by name, 27 other PAHs that had been identified in cigarette smoke were described as follows:

However, no less than 27 hydrocarbons containing four or more condensed rings which have been tested for carcinogenicity with negative results have been isolated from tobacco smoke tar.

Was the main reason for not naming any of the 27 PAHs specifically because none of the 27 possessed tumorigenic properties or was it because several were known to be effective antitumorigens vs. the very potent tumorigens $\mathrm{B}[a] \mathrm{P}$ and $\mathrm{DB}[a, h] \mathrm{A}$ ? Several reviewers (LEITER, SELIGMAN) of the draft of the chapter on tobacco and tobacco smoke composition were either complimentary or satisfied with it. However, in a late 1963 letter to the Advisory Committee Staff Director, KoTIN (56) listed the serious shortcomings that he and FALK felt were present in the draft of the chapter. In an earlier article, KOTIN and

\footnotetext{
${ }^{\mathrm{f}}$ In these three smoke composition studies, 1545 components were identified, 825 of which had not been reported previously in cigarette smoke, 720 of which were confirmation of previously reported tobacco smoke components.

$\mathrm{g}$ The nomenclature used in the listing is not that used in or before 1964 but is the current one defined by International Union of Pure and Applied Chemistry (IUPAC).
}

FALK (57) had summarized research findings on the anticarcinogenicity vs. $\mathrm{B}[a] \mathrm{P}$ or vs. $\mathrm{DB}[a, h] \mathrm{A}$ of nine PAHs (anthracene, benzo[a]fluorene, $\mathrm{B}[a] \mathrm{A}$, chrysene, pyrene, $\mathrm{B}[e] \mathrm{P}$, benzo[ $k]$ fluoranthene, benzo[ghi]fluoranthene, perylene), all of which had been identified in cigarette MSS prior to the Advisory Committee 1964 report and five of which were listed in its review [see Chapter 6 in (15)]. Twice in the Report [see pp. 143 and 144 (15)], anticarcinogens in tobacco smoke were mentioned by citation of a special KOTIN-FALK report to the Committee [see Reference 107, p. 242 in (15)], but no specific anticarcinogen was defined. Of the nearly 200 available publications by year-end 1963 on PAHs in cigarette smoke, only 15 publications were cited by FIESER and ORCHIN, the authors of the tobacco and smoke composition chapter in the Advisory Committee's report.

\section{ACKNOWLEDGMENTS}

The authors wish to acknowledge their great appreciation of the exceptional skill demonstrated by the late John J. Whalen in obtaining the meaningful IR spectra of extremely small samples of various PAHs and their derivatives and subsequently recovering the samples for additional study. Also greatly appreciated is the significant technical assistance provided during this study by two exceptionally talented technicians, Max A. Wagoner and the late Bruce W. Woosley.

\section{REFERENCES}

1. Rodgman, A.: The analysis of cigarette smoke condensate. I. The isolation and/or identification of polycyclic aromatic hydrocarbons in Camel cigarette smoke; RDR, 1956, No. 9, September 28, see www.rjrtdocs.com 501008241 -8293.

2. Rodgman, A.: The analysis of cigarette smoke condensate. IV. 3,4,8,9-Dibenzpyrene in Camel cigarette smoke condensate; RDR, 1957, No. 13, October 7, see www.rjitdocs.com $501008378-8386$.

3. Rodgman, A. and L.C. Cook: The analysis of cigarette smoke condensate. XIV. Polycyclic aromatic hydrocarbons; RDR, 1960, No. 20, May 26, see www.rjrtdocs.com $501008592-8660$.

4. Rodgman, A.: Studies of polycyclic aromatic hydrocarbons in cigarette mainstream smoke: Identification, tobacco precursors, control of levels: A review; Beitr. Tabakforsch. Int. 19 (2001) 361-379.

5. Lefemine, D.V., E.T. Alvord, and S.Z. Cardon: Identification of 3,4-benzpyrene in cigarette paper smoke and tars; Southeastern Reg. Mtg., Am. Chem. Soc., Birmingham, AL (1954).

6. Cardon, S.Z. and E.T. Alvord: The presence of 3,4benzpyrene in cigarette smoke; Ann. Mtg., Am. Assoc. Adv. Sci., Atlanta, GA (1955) pp. 1-12.

7. Alvord, E.T. and S.Z. Cardon: Separation and identification of 3,4-benzpyrene in cigarette smoke; $9^{\text {th }}$ Tobacco Chemists' Research Conference, Program Booklet and Abstracts, Vol. 9, Paper No. 24, 1955, p. 13. 
Table 4. The polycyclic aromatic hydrocarbons reported in tobacco smoke prior to $19644^{\mathrm{a}}$ :

\begin{tabular}{|c|c|c|c|}
\hline No. & Polycyclic Aromatic Hydrocarbon & CAS No. & References \\
\hline \multirow[t]{7}{*}{1} & Acenaphthylene & $208-96-8$ & 1956 Bonnet and Neukomm (58), Gilbert and Lindsey $(59,60)$ \\
\hline & & & 1957 Bonnet and Neukomm (28) \\
\hline & & & $\begin{array}{l}1959 \text { Bonnet and Neukomm (61, 62), Johnstone and Plimmer } \\
\text { (63), Pietzsch (64), Zapior et al. (65) }\end{array}$ \\
\hline & & & 1960 Rodgman and Cook (3) \\
\hline & & & 1962 Lyons (66) \\
\hline & & & 1963 Cook et al. (67), Philip Morris (16) \\
\hline & & & 1964 Elmenhorst and Reckzeh (18), USPHS (15) \\
\hline \multirow[t]{12}{*}{2} & Acenaphthylene, 1,2-dihydro- & $83-32-9$ & 1953 Cooper and Lindsey (68) \\
\hline & & & 1954 Cooper and Lindsey (69), Cooper et al. (70) \\
\hline & & & 1955 Cooper and Lindsey (71), Lindsey (72, Lyons (73)) \\
\hline & & & $\begin{array}{l}1956 \text { Bonnet and Neukomm (58), Campbell and Lindsey (74, } \\
\text { Gilbert and Lindsey }(59,60) \text {, Rodgman (1) }\end{array}$ \\
\hline & & & $\begin{array}{l}1957 \text { Bonnet and Neukomm (28), Campbell and Lindsey (75), } \\
\text { Wynder and Wright (76) }\end{array}$ \\
\hline & & & 1958 Wynder et al. (77) \\
\hline & & & $\begin{array}{l}1959 \text { Bonnet and Neukomm (61, 62), Johnstone and Plimmer } \\
\text { (63), Lindsey (78), Pietzsch (64) }\end{array}$ \\
\hline & & & 1960 Rodgman and Cook (3) \\
\hline & & & 1961 Alexandrov et al. (79) \\
\hline & & & 1962 Lyons (66) \\
\hline & & & 1963 Philip Morris (16) \\
\hline & & & 1964 Elmenhorst and Reckzeh (18), USPHS (15) \\
\hline \multirow[t]{13}{*}{3} & Anthracene & $120-12-7$ & 1953 Cooper and Lindsey (68) \\
\hline & & & $\begin{array}{l}1954 \text { Commins et al. (80), Cooper and Lindsey (69), Cooper et } \\
\text { al. (70) }\end{array}$ \\
\hline & & & $\begin{array}{l}1955 \text { Cooper and Lindsey (71), Lindsey (72), Lyons (73), } \\
\text { Seelkopf (81) }\end{array}$ \\
\hline & & & $\begin{array}{l}1956 \text { Bonnet and Neukomm (58), Campbell and Lindsey (74), } \\
\text { Gilbert and Lindsey }(59,60) \text {, Rodgman (1), Wright and } \\
\text { Wynder (82) }\end{array}$ \\
\hline & & & $\begin{array}{l}1957 \text { Bonnet and Neukomm (28), Campbell and Lindsey (75), } \\
\text { Wynder and Wright (76) }\end{array}$ \\
\hline & & & $\begin{array}{l}1958 \text { Ahlmann (83), Pietzsch (84), Scassellati-Sforzolini and } \\
\text { Salucci (85), Wynder and Wright (77) }\end{array}$ \\
\hline & & & $\begin{array}{l}1959 \text { Bonnet and Neukomm (62), Johnstone and Plimmer (63), } \\
\text { Lindsey }(78,86) \text {, Pietzsch (64), Zapior et al. (65) }\end{array}$ \\
\hline & & & $\begin{array}{l}1960 \text { Candeli et al. (87), Cuzin (88), Mouron et al. (89), } \\
\text { Rodgman and Cook (3) }\end{array}$ \\
\hline & & & 1960/61 Wynder (90) \\
\hline & & & $\begin{array}{l}1961 \text { Sasmoco (91), Scassellati-Sforzolini and Mariani }(92,93) \text {, } \\
\text { Scassellati-Sforzolini and Saldi (94) }\end{array}$ \\
\hline & & & 1962 Lyons (66), Parmele and Jensen (95), Pietzsch (96) \\
\hline & & & 1963 Cuzin et al. (97), Philip Morris (16) \\
\hline & & & 1964 Elmenhorst and Reckzeh (18), USPHS (15) \\
\hline \multirow[t]{2}{*}{4} & Anthracene, alkyl- & & 1955 Cooper and Lindsey (71), Lyons (73) \\
\hline & & & 1963 Philip Morris (16) \\
\hline \multirow[t]{2}{*}{5} & Anthracene, 9,10-dihydro- & $613-31-0$ & 1959 Pietzsch (64) \\
\hline & & & 1964 Elmenhorst and Reckzeh (18) \\
\hline 6 & Anthracene, methyl- & $26914-18-1$ & 1956 Dickey and Touey (98), Tennessee Eastman (99) \\
\hline \multirow[t]{4}{*}{7} & Anthracene, 2-methyl- & $613-12-7$ & 1955 Cooper and Lindsey (71) \\
\hline & & & 1959 Johnstone and Plimmer (63) \\
\hline & & & 1963 Philip Morris (16) \\
\hline & & & 1964 Elmenhorst and Reckzeh (18) \\
\hline 8 & Anthracene, 9-methyl- & $779-02-2$ & 1960 Rodgman and Cook (3) \\
\hline \multirow[t]{7}{*}{9} & Azulene & $275-51-4$ & 1947 Ikeda (43) \\
\hline & & & 1955 Lyons (73) \\
\hline & & & 1956 Gilbert and Lindsey $(59,60)$, Lyons (100) \\
\hline & & & 1958 Lyons (30) \\
\hline & & & 1959 Johnstone and Plimmer (63) \\
\hline & & & 1963 Philip Morris (16) \\
\hline & Benz[]]aceanthrylene, 1,2-dihydro- & $479-23-2$ & $\begin{array}{l}1964 \text { Elmenhorst and Reckzeh (18) } \\
1960 \text { Rodgman and Cook (3) }\end{array}$ \\
\hline
\end{tabular}




\begin{tabular}{|c|c|c|c|}
\hline No. & Polycyclic Aromatic Hydrocarbon & CAS No. & References \\
\hline 11 & $\begin{array}{l}\text { Benz[]]aceanthrylene, 1,2- dihydro-3- } \\
\text { methyl- }\end{array}$ & $56-49-5$ & $\begin{array}{l}1963 \text { Philip Morris (16) } \\
1964 \text { Kröller (101) }\end{array}$ \\
\hline \multirow[t]{2}{*}{12} & Benz[e]acephenanthrylene ${ }^{f}$ & $205-99-2$ & 1957 Wynder and Wright (76) \\
\hline & & & $\begin{array}{l}1959 \text { Hoffmann and Wynder (102), Johnstone and Plimmer } \\
\text { (63), Wynder and Hoffmann (103) } \\
1960 \text { Hoffmann and Wynder }(104,105) \\
\text { 1960/61 Wynder (90) } \\
1961 \text { Wynder and Hoffmann (106) } \\
1962 \text { Lyons (66) } \\
1964 \text { Elmenhorst and Reckzeh (18) }\end{array}$ \\
\hline \multirow[t]{11}{*}{13} & Benz[a]anthracene & $56-55-3$ & 1955 Lettré and Jahn (107), Lyons (73) \\
\hline & & & $\begin{array}{l}1956 \text { Bonnet and Neukomm (58), Gilbert and Lindsey }(59,60) \text {, } \\
\text { Lyons (100), Rodgman (1) }\end{array}$ \\
\hline & & & $\begin{array}{l}1957 \text { Bonnet and Neukomm (28), Lyons and Johnston (29), } \\
\text { Neukomm and Bonnet (108), Pietzsch (64), Rand et al. } \\
\text { (109) }\end{array}$ \\
\hline & & & 1958 Ahlmann (83), Pietzsch (84), Wynder et al. (77) \\
\hline & & & $\begin{array}{l}1959 \text { Bonnet and Neukomm }(61,62) \text {, Johnstone and Plimmer } \\
\text { (63), Pietzsch (64), Wynder and Hoffmann (110) }\end{array}$ \\
\hline & & & 1960 Rodgman and Cook (3), Hoffmann and Wynder (105) \\
\hline & & & 1960/61 Wynder (90) \\
\hline & & & 1962 Lyons (66), Pietzsch (96) \\
\hline & & & 1962/63 Pyriki (32) \\
\hline & & & 1963 Philip Morris (16) \\
\hline & & & 1964 Elmenhorst and Reckzeh (18), USPHS (15) \\
\hline \multirow[t]{5}{*}{14} & Benz[a]anthracene, 7,12-dimethyl- & $57-97-6$ & 1958 Pietzsch (84) \\
\hline & & & 1959 Johnstone and Plimmer (63), Pietzsch (64) \\
\hline & & & 1962 Lyons (66) \\
\hline & & & 1963 Philip Morris (16) \\
\hline & & & 1964 Elmenhorst and Reckzeh (18), Kröller (101) \\
\hline \multirow[t]{7}{*}{15} & Benz[a]anthracene, 5-methyl- & $2319-96-2$ & 1956 Bonnet and Neukomm (58) \\
\hline & & & 1957 Neukomm and Bonnet (108) \\
\hline & & & 1959 Johnstone and Plimmer (63) \\
\hline & & & 1960 Rodgman and Cook (3) \\
\hline & & & 1962/63 Pyriki (32) \\
\hline & & & 1963 Philip Morris (16) \\
\hline & & & 1964 Elmenhorst and Reckzeh (18), \\
\hline \multirow[t]{8}{*}{16} & 1H-Benzo[a]cyclopent $[h]$ anthracene, $2,3-$ & $7099-43-6$ & 1956 Bonnet and Neukomm (58) \\
\hline & dihydro- & & $\begin{array}{l}1957 \text { Bonnet and Neukomm (28), Lyons and Johnston (29), } \\
\text { Neukomm and Bonnet (108) }\end{array}$ \\
\hline & & & 1958 Bonnet (111), British Empire Cancer Campaign (112) \\
\hline & & & 1959 Bonnet and Neukomm (61), Johnstone and Plimmer (63) \\
\hline & & & 1960 Rodgman and Cook (3) \\
\hline & & & 1962/63 Pyriki (32) \\
\hline & & & 1963 Philip Morris (16) \\
\hline & & & 1964 Elmenhorst and Reckzeh (18) \\
\hline \multirow[t]{8}{*}{17} & $9 H$-Benzo[a]cyclopent[i]anthracene, 10,11- & $7099-42-5$ & 1956 Bonnet and Neukomm (58) \\
\hline & dihydro- & & $\begin{array}{l}1957 \text { Bonnet and Neukomm (28), Lyons and Johnston (29), } \\
\text { Neukomm and Bonnet (108) }\end{array}$ \\
\hline & & & 1958 Ahlmann (83), Bonnet (111) \\
\hline & & & 1959 Bonnet and Neukomm (61), Johnstone and Plimmer (63) \\
\hline & & & 1960 Rodgman and Cook (3) \\
\hline & & & 1962/63 Pyriki (32) \\
\hline & & & 1963 Philip Morris (16) \\
\hline & & & 1964 Elmenhorst and Reckzeh (18) \\
\hline \multirow[t]{2}{*}{18} & Benzo[cd]fluoranthene & $16135-81-2$ & 1959 Bentley and Berry (113) \\
\hline & & & 1963 Philip Morris (16) \\
\hline \multirow[t]{2}{*}{19} & Benzo[ghifluoranthene & $203-12-3$ & 1957 Lyons and Johnston (29) \\
\hline & & & $\begin{array}{l}1958 \text { Van Duuren (114), Van Duuren and Nelson (115), Wynder } \\
\text { et al. (77) }\end{array}$ \\
\hline
\end{tabular}




\begin{tabular}{|c|c|c|c|}
\hline No. & Polycyclic Aromatic Hydrocarbon & CAS No. & References \\
\hline \multirow[t]{7}{*}{19} & Benzo[ghi]fluoranthene (cont.) & $203-12-3$ & $\begin{array}{l}1959 \text { Johnstone and Plimmer (63), Wynder and Hoffmann (103, } \\
\text { 106) }\end{array}$ \\
\hline & & & 1960 Rodgman and Cook (3) \\
\hline & & & 1963 Philip Morris (16) \\
\hline & & & 1960 Hoffmann and Wynder $(104,105)$ \\
\hline & & & 1960/61 Wynder (90) \\
\hline & & & 1961 Wynder and Hoffmann (110) \\
\hline & & & 1964 Elmenhorst and Reckzeh (18) \\
\hline \multirow[t]{7}{*}{20} & Benzo[]]fluoranthene & $205-82-3$ & 1958 Van Duuren and Nelson (115) \\
\hline & & & $\begin{array}{l}1959 \text { Johnstone and Plimmer (63), Wynder and Hoffmann (103, } \\
\text { 106) }\end{array}$ \\
\hline & & & 1960 Hoffmann and Wynder $(104,105)$, Rodgman and Cook (3) \\
\hline & & & 1960/61 Wynder (90) \\
\hline & & & 1961 Wynder and Hoffmann (110) \\
\hline & & & 1963 Philip Morris (16) \\
\hline & & & 1964 Elmenhorst and Reckzeh (18), USPHS (15) \\
\hline \multirow[t]{9}{*}{21} & Benzo[k]fluoranthene & $207-08-9$ & 1956 Lyons (100) \\
\hline & & & 1957 Lyons and Johnston (29) \\
\hline & & & $\begin{array}{l}1958 \text { British Empire Cancer Campaign (112), Lyons (30), Van } \\
\text { Duuren (114), Van Duuren and Nelson (115) }\end{array}$ \\
\hline & & & $\begin{array}{l}1959 \text { Johnstone and Plimmer (63), Tennessee Eastman (), } \\
\text { Wynder and Hoffmann }(103,106)\end{array}$ \\
\hline & & & 1960 Rodgman and Cook (3), Hoffmann and Wynder $(104,105)$ \\
\hline & & & 1961 Wynder and Hoffmann (110) \\
\hline & & & 1962 Lyons (66) \\
\hline & & & 1963 Philip Morris (16) \\
\hline & & & 1964 Elmenhorst and Reckzeh (18) \\
\hline \multirow[t]{2}{*}{22} & $5 H$-Benzo[a]fluorene & $238-79-9$ & 1963 Mold et al. (117), Philip Morris (16) \\
\hline & & & 1964 Elmenhorst and Reckzeh (18) \\
\hline \multirow[t]{6}{*}{23} & $11 H$-Benzo[a]fluorene & $238-84-6$ & 1956 Bonnet and Neukomm (58) \\
\hline & & & 1957 Bonnet and Neukomm (28), Neukomm and Bonnet (108) \\
\hline & & & $\begin{array}{l}1958 \text { Ahlmann (83), Van Duuren and Nelson (115), Wynder et } \\
\text { al. (77) }\end{array}$ \\
\hline & & & 1962 Pietzsch (96) \\
\hline & & & 1963 Philip Morris (16) \\
\hline & & & 1964 Elmenhorst and Reckzeh (18) \\
\hline \multirow[t]{6}{*}{24} & 11H-Benzo[a]fluorene, 11-methyl- & $71265-25-3$ & 1956 Bonnet and Neukomm (58) \\
\hline & & & 1957 Neukomm and Bonnet (108) \\
\hline & & & 1958 AhImann (83) \\
\hline & & & 1959 Johnstone and Plimmer (63), Tennessee Eastman (116) \\
\hline & & & 1963 Philip Morris (16) \\
\hline & & & 1964 Elmenhorst and Reckzeh (18) \\
\hline \multirow[t]{6}{*}{25} & $11 H$-Benzo[b]fluorene & $243-17-4$ & 1958 Ahlmann (83) \\
\hline & & & 1959 Johnstone and Plimmer (63) \\
\hline & & & 1960 Hoffmann and Wynder (105) \\
\hline & & & 1960/61 Wynder (90) \\
\hline & & & 1963 Philip Morris (16) \\
\hline & & & 1964 Elmenhorst and Reckzeh (18) \\
\hline \multirow[t]{2}{*}{26} & 7H-Benzo[c]fluorene & $205-12-9$ & 1958 Wynder et al. (77) \\
\hline & & & 1964 Elmenhorst and Reckzeh (18) \\
\hline \multirow[t]{4}{*}{27} & Benzo[a]naphthacene & $226-88-0$ & 1957 Wynder and Wright (76) \\
\hline & & & 1959 Johnstone and Plimmer (63) \\
\hline & & & 1963 Philip Morris (16) \\
\hline & & & 1964 Elmenhorst and Reckzeh (18) \\
\hline \multirow[t]{5}{*}{28} & Benzo[rst]pentaphene & $189-55-9$ & 1956 Bonnet and Neukomm (58) \\
\hline & & & $\begin{array}{l}1957 \text { Bonnet and Neukomm (28), Neukomm and Bonnet (108), } \\
\text { Wynder and Wright (76) }\end{array}$ \\
\hline & & & 1958 Bonnet (111), Wynder et al. (77) \\
\hline & & & 1959 Bonnet and Neukomm $(61,62)$ \\
\hline & & & 1960 Rodgman and Cook (3) \\
\hline
\end{tabular}




\begin{tabular}{|c|c|c|c|}
\hline No. & Polycyclic Aromatic Hydrocarbon & CAS No. & References \\
\hline \multirow[t]{4}{*}{28} & Benzo[rst]pentaphene (cont.) & $189-55-9$ & 1962 Neukomm (118), Pietzsch (96) \\
\hline & & & 1962/63 Pyriki (32) \\
\hline & & & 1963 Gil-Av and Shabtai (119) \\
\hline & & & 1964 Elmenhorst and Reckzeh (18), USPHS (15) \\
\hline \multirow[t]{12}{*}{29} & Benzo[ghi]perylene & $191-24-2$ & 1954 Cooper and Lindsey (69) \\
\hline & & & 1955 Cooper and Lindsey (71), Lindsey (72), Lyons (73) \\
\hline & & & 1956 Rodgman (1) \\
\hline & & & 1957 Lyons and Johnston (29) \\
\hline & & & $\begin{array}{l}1958 \text { Ahlmann (83), British Empire Cancer Campaign (112), } \\
\text { Pietzsch (84), Van Duuren (120), Van Duuren and Nelson } \\
\text { (115), Wynder et al. (77) }\end{array}$ \\
\hline & & & $\begin{array}{l}1959 \text { Johnstone and Plimmer (63), Pietzsch (64), Tennessee } \\
\text { Eastman (116), Wynder and Hoffmann }(103,110)\end{array}$ \\
\hline & & & 1960 Hoffmann and Wynder $(104,105)$, Rodgman and Cook (3) \\
\hline & & & 1960/61 Wynder (90) \\
\hline & & & 1962 Lyons (66) \\
\hline & & & 1962/1963 Pyriki (32) \\
\hline & & & 1963 Philip Morris (16) \\
\hline & & & 1964 Elmenhorst and Reckzeh (18), USPHS (15) ${ }^{\mathrm{d}}$ \\
\hline \multirow[t]{5}{*}{30} & Benzo[c]phenanthrene & $195-19-7$ & $\begin{array}{l}1958 \text { British Empire Cancer Campaign (112), Van Duuren (114), } \\
\text { Van Duuren and Nelson (115), Wynder et al. (77) }\end{array}$ \\
\hline & & & 1959 Johnstone and Plimmer (63) \\
\hline & & & 1960 Rodgman and Cook (3) \\
\hline & & & 1963 Philip Morris (16) \\
\hline & & & 1964 Elmenhorst and Reckzeh (18), USPHS (15) \\
\hline \multirow[t]{12}{*}{31} & Benzo[a]pyrene & $50-32-8$ & 1952 Hofer and Peebles (38) \\
\hline & & & 1954 Cooper and Lindsey (69), Cooper et al. (70) \\
\hline & & & $\begin{array}{l}1955 \text { Cardon and Alvord (6), Alvord and Cardon (7), Cooper } \\
\text { and Lindsey (71), Lettré and Jahn (107), Lindsey (72), } \\
\text { Seelkopf (81), Wieske (121, Wright and Wynder (122) }\end{array}$ \\
\hline & & & 1955/56 Alvord and Cardon (123), Falk and Kotin (124) \\
\hline & & & $\begin{array}{l}1956 \text { Babin et al. (125),Bonnet and Neukomm (58), Campbell } \\
\text { and Lindsey (74), Cardon et al. (126), Gilbert and Lindsey } \\
\text { (59, 60), Kuratsune (127), Lam (128), Lettré et al. (129), } \\
\text { Lyons (100), Rodgman (1), Wright and Wynder (82), } \\
\text { Wynder and Wright (130) }\end{array}$ \\
\hline & & & 1956/57 Wright (131) \\
\hline & & & $\begin{array}{l}1957 \text { Bonnet and Neukomm (28), Campbell and Lindsey (75), } \\
\text { Fieser (9), Lyons and Johnston (29), Neukomm (118, } \\
\text { 132), Neukomm and Bonnet (108), Rand et al. (109), } \\
\text { Wieske (133), Wynder and Wright (76) }\end{array}$ \\
\hline & & & $\begin{array}{l}1958 \text { Ahlmann (83), } 1958 \text { Bentley and Burgan (134, Cardon } \\
\text { (135), Clemo (136), Cuzin (137), Hubert-Habart et al. } \\
\text { (138), Latarjet et al. (139), Orris et al. (10), Pietzsch (84), } \\
\text { Scassellati-Sforzolini and Salucci (85), Van Duuren (114, } \\
\text { 120, 140), Van Duuren and Nelson (115), Wynder et al. } \\
\text { (77) }\end{array}$ \\
\hline & & & $\begin{array}{l}1959 \text { Bonnet and Neukomm }(61,62), \text { Burgan (141), Dikun (142, } \\
\text { Dikun and Chushkin (143), Hoffmann and Wynder (102), } \\
\text { Johnstone and Plimmer (63), Lindsey (78, 86), Lindsey et } \\
\text { al. (144), Pietzsch (64), Tennessee Eastman (145), } \\
\text { Wynder and Hoffmann (103, 110), Wynder et al. (146), } \\
\text { Zapior et al. (65) }\end{array}$ \\
\hline & & & $\begin{array}{l}1960 \text { Bentley and Burgan (147, 148), Candeli et al. (149), } \\
\text { Clemo 150), Cuzin (88), Cuzin et al. (151), Dikun et al. } \\
\text { (152), Hoffmann and Wynder (104, 105), Hubert-Habart } \\
\text { (153), Mouron et al. (89), Pavlu and Sula (154), Rodgman } \\
\text { and Cook (3), Takayama and Oota (155) }\end{array}$ \\
\hline & & & 1960/61 Wynder $(90)$ \\
\hline & & & $\begin{array}{l}1961 \text { Alexandrov et al. (79), Grimmer (156), Guérin (157), } \\
\text { Mouron et al. (158), Rand et al. 159), Sasmoco (91), } \\
\text { Scassellati-Sforzolini and Mariani (92, 93), Scassellati- } \\
\text { Sforzolini and Saldi (94), Wynder and Hoffmann (106) }\end{array}$ \\
\hline
\end{tabular}




\begin{tabular}{|c|c|c|c|}
\hline No. & Polycyclic Aromatic Hydrocarbon & CAS No. & References \\
\hline \multirow[t]{4}{*}{31} & Benzo[a]pyrene (cont.) & $50-32-8$ & $\begin{array}{l}1962 \text { Barkemeyer (160), Bell (161), Bentley (162), Dikun et al. } \\
\text { (163), Lyons (66), Neukomm (118), Parmele and Jensen } \\
\text { (95), Pietzsch (96) }\end{array}$ \\
\hline & & & 1962/63 Pyriki (32) \\
\hline & & & $\begin{array}{l}1963 \text { Cuzin et al. (97), Druckrey and Schildbach (164), Gil-Av } \\
\text { and Shabtai (119), Hoffmann et al. (165), Philip Morris } \\
\text { (16), Scherbak et al. (166), Testa et al. (167), Waltz and } \\
\text { Häusermann (168) }\end{array}$ \\
\hline & & & $\begin{array}{l}1964 \text { Elmenhorst and Reckzeh (18), Fieser (11), Kröller (101), } \\
\text { USPHS (15) }\end{array}$ \\
\hline \multirow[t]{3}{*}{32} & Benzo[a]pyrene, alkyl- & & 1958 Wynder et al. (77) \\
\hline & & & 1963 Philip Morris (16) \\
\hline & & & 1964 Elmenhorst and Reckzeh (18) \\
\hline \multirow[t]{4}{*}{33} & Benzo[a]pyrene, 7,8-dihydro- & $17573-23-8$ & 1958 Ahlmann (83) \\
\hline & & & 1959 Johnstone and Plimmer (63) \\
\hline & & & 1963 Philip Morris (16) \\
\hline & & & 1964 Elmenhorst and Reckzeh (18) \\
\hline 34 & Benzo[a]pyrene, dimethyl- & $25167-90-2$ & 1958 Clemo (136) \\
\hline \multirow[t]{3}{*}{35} & Benzo[a]pyrene, methyl- & 25167-89-9 & 1958 Van Duuren (120), Van Duuren and Nelson (115) \\
\hline & & & 1960 Rodgman and Cook (3) \\
\hline & & & 1963 Philip Morris (16) \\
\hline \multirow[t]{9}{*}{36} & Benzo[e]pyrene & $192-97-2$ & 1955 Lettré and Jahn (107) \\
\hline & & & 1957 Lyons and Johnston (29) \\
\hline & & & $\begin{array}{l}1958 \text { Ahlmann (83), British Empire Cancer Campaign (112), } \\
\text { Orris et al. (10), Pietzsch (84), Van Duuren (114, 120, } \\
\text { 140), Van Duuren and Nelson (115), Wynder et al. (77) }\end{array}$ \\
\hline & & & $\begin{array}{l}1959 \text { Hoffmann and Wynder (102), Johnstone and Plimmer } \\
\text { (63), Pietzsch (64), Wynder and Hoffmann }(103,110)\end{array}$ \\
\hline & & & 1960 Hoffmann and Wynder $(104,105)$, Rodgman and Cook (3) \\
\hline & & & 1960/61 Wynder (90) \\
\hline & & & 1962 Lyons (66), Pietzsch (96) \\
\hline & & & 1963 Philip Morris (16) \\
\hline & & & 1964 Elmenhorst and Reckzeh (18), USPHS (15) ${ }^{\mathrm{d}}$ \\
\hline 37 & 2,2'-Binaphthalene & $612-78-2$ & 1961 Izawa (169) \\
\hline \multirow[t]{9}{*}{38} & Chrysene & $218-01-9$ & 1956 Wright and Wynder (82) \\
\hline & & & 1957 Lyons and Johnston (29), Rand et al. (109) \\
\hline & & & $\begin{array}{l}1958 \text { Ahlmann (83), British Empire Cancer Campaign (112), } \\
\text { Pietzsch (84), Van Duuren (120, Van Duuren and Nelson } \\
\text { (115), Wynder et al. (77) }\end{array}$ \\
\hline & & & $\begin{array}{l}1959 \text { Hoffmann and Wynder (102), Johnstone and Plimmer } \\
\text { (63), Pietzsch (64), Wynder and Hoffmann }(103,110)\end{array}$ \\
\hline & & & 1960 Hoffmann and Wynder $(104,105)$, Rodgman and Cook (3) \\
\hline & & & 1960/61 Wynder (90) \\
\hline & & & 1962 Lyons (66) \\
\hline & & & 1963 Philip Morris (16) \\
\hline & & & 1964 Elmenhorst and Reckzeh (18) \\
\hline \multirow[t]{6}{*}{39} & Chrysene, alkyl- & & 1958 Van Duuren (114), Wynder et al. (77) \\
\hline & & & $\begin{array}{l}1959 \text { Johnstone and Plimmer (63), Wynder and Hoffmann (103, } \\
\text { 110) }\end{array}$ \\
\hline & & & 1960 Hoffmann and Wynder $(104,105)$, Rodgman and Cook (3) \\
\hline & & & $1960 / 61$ Wynder (90) \\
\hline & & & 1963 Philip Morris (16), Hoffmann and Wynder $(104,105)$ \\
\hline & & & 1964 Elmenhorst and Reckzeh (18) \\
\hline \multirow[t]{6}{*}{40} & Chrysene, dimethyl- & $41637-92-7$ & 1958 Ahlmann (83) \\
\hline & & & 1959 Johnstone and Plimmer (63) \\
\hline & & & 1960 Hubert-Habart (153) \\
\hline & & & 1962/63 Pyriki (32) \\
\hline & & & 1963 Philip Morris (16) \\
\hline & & & 1964 Elmenhorst and Reckzeh (18) \\
\hline \multirow[t]{3}{*}{41} & Chrysene, 1-methyl- & $3351-28-8$ & 1958 Ahlmann (83), Van Duuren and Nelson (115) \\
\hline & & & 1963 Philip Morris (16) \\
\hline & & & 1964 Elmenhorst and Reckzeh (18) \\
\hline
\end{tabular}




\begin{tabular}{|c|c|c|c|}
\hline No. & Polycyclic Aromatic Hydrocarbon & CAS No. & References \\
\hline \multirow[t]{7}{*}{42} & Coronene & $191-07-1$ & 1956 Gilbert and Lindsey $(59,60)$ \\
\hline & & & 1958 Pietzsch (84), Wynder et al. (77) \\
\hline & & & $\begin{array}{l}1959 \text { Johnstone and Plimmer (63), Lindsey (86), Pietzsch (64), } \\
\text { Tennessee Eastman (116) }\end{array}$ \\
\hline & & & 1960 Candeli et al. (87), Rodgman and Cook (3) \\
\hline & & & 1962 Lyons (66) \\
\hline & & & 1963 Philip Morris (16) \\
\hline & & & 1964 Elmenhorst and Reckzeh (18), USPHS (15) ${ }^{d}$ \\
\hline \multirow[t]{2}{*}{43} & 15H-Cyclopenta[a]phenanthrene & $219-07-8$ & 1959 Tennessee Eastman (116) \\
\hline & & & 1964 Elmenhorst and Reckzeh (18) \\
\hline \multirow[t]{4}{*}{44} & 15H-Cyclopenta[a]phenanthrene, 16,17- & $482-66-6$ & 1958 Wynder et al. (77) \\
\hline & dihydro- & & 1959 Tennessee Eastman (116) \\
\hline & & & 1963 Philip Morris (16) \\
\hline & & & 1964 Elmenhorst and Reckzeh (18) \\
\hline \multirow[t]{2}{*}{45} & 4H-Cyclopenta[def]phenanthrene & $203-64-5$ & 1963 Philip Morris (16) \\
\hline & & & 1964 Kröller (101) \\
\hline \multirow[t]{8}{*}{46} & Dibenz[a,h]anthracene & $53-70-3$ & $\begin{array}{l}1958 \text { Pietzsch (84), Van Duuren (114), Van Duuren and Nelson } \\
\text { (115), Wynder et al. (77) }\end{array}$ \\
\hline & & & $\begin{array}{l}1959 \text { Johnstone and Plimmer (63), Pietzsch (64), Tennessee } \\
\text { Eastman (116), Wynder and Hoffmann }(103,110)\end{array}$ \\
\hline & & & 1960 Hoffmann and Wynder $(104,105)$ \\
\hline & & & 1960 Rodgman and Cook (3) \\
\hline & & & 1960/61 Wynder (90) \\
\hline & & & 1962 Lyons (66) \\
\hline & & & 1963 Philip Morris (16) \\
\hline & & & 1964 Elmenhorst and Reckzeh (18), Kröller (101), USPHS (15) \\
\hline \multirow[t]{7}{*}{47} & Dibenzo[b,def]chrysene & 189-64-0 & 1957 Lyons and Johnston (29), Wynder and Wright (76) \\
\hline & & & 1958 British Empire Cancer Campaign (112), Wynder et al. (77) \\
\hline & & & 1959 Johnstone and Plimmer (63) \\
\hline & & & 1960 Rodgman and Cook (3) \\
\hline & & & 1962/63 Pyriki (32) \\
\hline & & & 1963 Philip Morris (16) \\
\hline & & & 1964 Elmenhorst and Reckzeh (18) \\
\hline \multirow[t]{9}{*}{48} & Dibenzo[def,mno]chrysene & $191-26-4$ & 1954 Cooper and Lindsey (69) \\
\hline & & & 1955 Cooper and Lindsey (71), Lindsey (72) \\
\hline & & & 1956 Gilbert and Lindsey $(59,60)$, Rodgman (1) \\
\hline & & & 1957 Lyons and Johnston (29) \\
\hline & & & 1958 Pietzsch (84), Scassellati-Sforzolini and Salucci (85) \\
\hline & & & $\begin{array}{l}1959 \text { Johnstone and Plimmer (63), Lindsey (86), Pietzsch (64), } \\
\text { Tennessee Eastman (116) }\end{array}$ \\
\hline & & & 1960 Hoffmann and Wynder (105), Rodgman and Cook (3) \\
\hline & & & 1962 Lyons (66) \\
\hline & & & 1964 Elmenhorst and Reckzeh (18), USPHS (15) ${ }^{d}$ \\
\hline \multirow[t]{6}{*}{49} & Dibenzo[def,p]chrysene ${ }^{g}$ & $191-30-0$ & 1957 Rodgman (2) \\
\hline & & & 1958 Lyons (30) \\
\hline & & & 1959 Johnstone and Plimmer (63), Schoental (170) \\
\hline & & & 1960 Rodgman and Cook (3) \\
\hline & & & 1963 Philip Morris (16) \\
\hline & & & 1964 Elmenhorst and Reckzeh (18), USPHS (15) \\
\hline \multirow[t]{7}{*}{50} & 13H-Dibenzo[a,i]fluorene & $239-60-1$ & 1957 Lyons and Johnston (29) \\
\hline & & & 1958 British Empire Cancer Campaign (112) \\
\hline & & & 1959 Johnstone and Plimmer (63) \\
\hline & & & 1960 Hubert-Habart (153) \\
\hline & & & 1962/63 Pyriki (32) \\
\hline & & & 1963 Philip Morris (16) \\
\hline & & & 1964 Elmenhorst and Reckzeh (18) \\
\hline \multirow[t]{5}{*}{51} & Dibenzo[a,c]naphthacene & $216-00-2$ & 1957 Lyons and Johnston (29) \\
\hline & & & 1958 British Empire Cancer Campaign (112) \\
\hline & & & 1959 Johnstone and Plimmer (63) \\
\hline & & & 1963 Philip Morris (16) \\
\hline & & & 1964 Elmenhorst and Reckzeh (18) \\
\hline
\end{tabular}




\begin{tabular}{|c|c|c|c|}
\hline No. & Polycyclic Aromatic Hydrocarbon & CAS No. & References \\
\hline \multirow[t]{4}{*}{52} & Dibenzo[a,j]naphthacene & $227-04-3$ & 1957 Wynder and Wright (76) \\
\hline & & & 1958 Wynder et al. (77) \\
\hline & & & 1959 Johnstone and Plimmer (63) \\
\hline & & & 1963 Philip Morris (16) \\
\hline \multirow{14}{*}{$\begin{array}{l}53 \\
54 \\
55\end{array}$} & Dibenzo[de,qr]naphthacene & $193-09-9$ & 1960 Rodgman and Cook (3), \\
\hline & Dibenzopyrene & $58615-36-4$ & 1959 Bonnet and Neukomm (61) \\
\hline & Fluoranthene & $206-44-0$ & 1954 Cooper and Lindsey (69) \\
\hline & & & 1955 Cooper and Lindsey (71), Lindsey (72) \\
\hline & & & $\begin{array}{l}1956 \text { Campbell and Lindsey (74), Gilbert and Lindsey }(59,60) \text {, } \\
\text { Rodgman (1), Wright and Wynder (82) }\end{array}$ \\
\hline & & & $\begin{array}{l}1957 \text { Campbell and Lindsey (75), Lyons and Johnston (29), } \\
\text { Wynder and Wright (76) }\end{array}$ \\
\hline & & & $\begin{array}{l}1958 \text { Ahlmann (83), , Pietzsch (84), Scassellati-Sforzolini and } \\
\text { Salucci (85), Van Duuren (114, 120, 140), Van Duuren } \\
\text { and Nelson (115), Wynder et al. (77) }\end{array}$ \\
\hline & & & $\begin{array}{l}1959 \text { Johnstone and Plimmer (63), Lindsey }(78,86) \text {, Lindsey et } \\
\text { al. (144), Pietzsch (64), Wynder and Hoffmann }(103,110) \text {, } \\
\text { Zapior et al. (65) }\end{array}$ \\
\hline & & & $\begin{array}{l}1960 \text { Candeli et al. (87), Hoffmann and Wynder }(104,105) \text {, } \\
\text { Rodgman and Cook (3) }\end{array}$ \\
\hline & & & 1960/61 Wynder (90) \\
\hline & & & $\begin{array}{l}1961 \text { Scassellati-Sforzolini and Mariani (92, 93), Scassellati- } \\
\text { Sforzolini and Saldi (94) }\end{array}$ \\
\hline & & & 1962 Lyons (66), Pietzsch (96) \\
\hline & & & 1963 Cook et al. (67), Philip Morris (16) \\
\hline & & & 1964 Elmenhorst and Reckzeh (18), Kröller (101), USPHS (15) ${ }^{d}$ \\
\hline \multirow[t]{5}{*}{56} & Fluoranthene, alkyl- & & 1958 Van Duuren (140), Van Duuren and Nelson (115) \\
\hline & & & 1959 Wynder and Hoffmann (103) \\
\hline & & & 1960 Hoffmann and Wynder (105), Rodgman and Cook (3) \\
\hline & & & 1960/61 Wynder (90) \\
\hline & & & 1964 Elmenhorst and Reckzeh (18) \\
\hline \multirow[t]{4}{*}{57} & Fluoranthene, dimethyl- & $60826-74-6$ & 1958 Van Duuren and Nelson (115) \\
\hline & & & 1959 Johnstone and Plimmer (63) \\
\hline & & & 1963 Philip Morris (16) \\
\hline & & & 1964 Elmenhorst and Reckzeh (18) \\
\hline \multirow[t]{2}{*}{58} & Fluoranthene, 8,9-dimethyl- & $25889-63-8$ & 1963 Philip Morris (16) \\
\hline & & & 1959 Bentley and Berry (113) \\
\hline \multirow[t]{3}{*}{59} & Fluoranthene, 8-methyl- & $20485-57-8$ & $\begin{array}{l}1958 \text { Van Duuren }(114,120,140) \text {, Van Duuren and Nelson } \\
(115)\end{array}$ \\
\hline & & & 1963 Philip Morris (16) \\
\hline & & & 1964 Elmenhorst and Reckzeh (18) \\
\hline \multirow[t]{8}{*}{60} & $9 \mathrm{H}$-Fluorene & $86-73-7$ & 1956 Bonnet and Neukomm (58), Gilbert and Lindsey $(59,60)$ \\
\hline & & & 1957 Bonnet and Neukomm (28), Neukomm and Bonnet (108) \\
\hline & & & 1958 AhImann (83), Pietzsch (84) \\
\hline & & & 1959 Johnstone and Plimmer (63), Pietzsch (64) \\
\hline & & & 1960 Rodgman and Cook (3) \\
\hline & & & 1962 Lyons (66), Pietzsch (96) \\
\hline & & & 1963 Philip Morris (16) \\
\hline & & & 1964 Elmenhorst and Reckzeh (18), USPHS (15) \\
\hline \multirow[t]{2}{*}{61} & 9H-Fluorene, 1-methyl- & $1730-37-6$ & 1963 Philip Morris (16) \\
\hline & & & 1964 Elmenhorst and Reckzeh (18) \\
\hline \multirow[t]{5}{*}{62} & 9H-Fluorene, 9-methyl- & 2523-37-7 & 1956 Bonnet and Neukomm (58) \\
\hline & & & 1957 Neukomm and Bonnet (108) \\
\hline & & & 1958 Van Duuren (120) \\
\hline & & & 1963 Philip Morris (16) \\
\hline & & & 1964 Elmenhorst and Reckzeh (18) \\
\hline 63 & $1 H$-Indene & $95-13-6$ & 1963 Cook et al. (67), Philip Morris (16) \\
\hline \multirow[t]{2}{*}{64} & Indeno[1,2,3-cd]fluoranthene & $193-43-1$ & 1960 Hoffmann and Wynder (105) \\
\hline & & & 1964 Elmenhorst and Reckzeh (18) \\
\hline \multirow[t]{2}{*}{65} & $11 H$-Indeno[2,1-a]phenanthrene ${ }^{h}$ & $220-97-3$ & 1958 Ahlmann (83) \\
\hline & & & 1959 Johnstone and Plimmer (63) \\
\hline \multirow[t]{3}{*}{66} & Indeno[1,2,3-cd]pyrene & $193-39-5$ & 1960 Hoffmann and Wynder (105) \\
\hline & & & 1964 Elmenhorst and Reckzeh (18) \\
\hline & & & 1964 Elmenhorst and Reckzeh (18) \\
\hline
\end{tabular}


Table 4. (cont.)

\begin{tabular}{|c|c|c|c|}
\hline No. & Polycyclic Aromatic Hydrocarbon & CAS No. & References \\
\hline \multirow[t]{3}{*}{67} & Naphthacene & $92-24-0$ & 1962 Pietzsch (96) \\
\hline & & & 1963 Cook et al. (67) \\
\hline & & & 1964 Elmenhorst and Reckzeh (18) \\
\hline \multirow[t]{10}{*}{68} & Naphthalene & $91-20-3$ & 1954 Commins et al. (80) \\
\hline & & & 1955 Seelkopf (81) \\
\hline & & & $\begin{array}{l}1956 \text { Bonnet and Neukomm (58), Gilbert and Lindsey }(59,60) \text {, } \\
\text { Rodgman (1) }\end{array}$ \\
\hline & & & 1957 Bonnet and Neukomm (28), Lyons and Johnston (29) \\
\hline & & & 1958 Pietzsch (84), Wynder et al. (77) \\
\hline & & & 1959 Johnstone and Plimmer (63), Pietzsch (64) \\
\hline & & & 1960 Rodgman and Cook (3) \\
\hline & & & 1962 Lyons (66) \\
\hline & & & 1963 Johnstone and Quan (171), Philip Morris (16) \\
\hline & & & 1964 Elmenhorst and Reckzeh (18) \\
\hline 69 & Naphthalene, alkyl- & & 1963 Johnstone and Quan (171) \\
\hline 70 & Naphthalene, 1,2-dihydro-4-methyl- & 4373-13-1 & 1960 Rodgman and Cook (3) \\
\hline \multirow[t]{2}{*}{71} & Naphthalene, 1,6-dimethyl- & $575-43-9$ & 1963 Johnstone and Quan (171) \\
\hline & & & 1964 Elmenhorst and Reckzeh (18) \\
\hline \multirow[t]{4}{*}{72} & Naphthalene, 1,8-dimethyl- & $569-41-5$ & 1956 Bonnet and Neukomm (58) \\
\hline & & & 1959 Bentley and Berry (113), Johnstone and Plimmer (63) \\
\hline & & & 1963 Philip Morris (16) \\
\hline & & & 1964 Elmenhorst and Reckzeh (18) \\
\hline \multirow[t]{2}{*}{73} & Naphthalene, 2,6-dimethyl- & $581-42-0$ & 1963 Johnstone and Quan (171) \\
\hline & & & 1964 Elmenhorst and Reckzeh (18) \\
\hline \multirow[t]{2}{*}{74} & Naphthalene, 2,7-dimethyl- & $582-16-1$ & 1963 Johnstone and Quan (171) \\
\hline & & & 1964 Elmenhorst and Reckzeh (18) \\
\hline \multirow[t]{5}{*}{75} & Naphthalene, 1-methyl- & $90-12-0$ & 1952 Soffer and Stewart (39) \\
\hline & & & 1960 Rodgman and Cook (3) \\
\hline & & & 1961 Guérin (157) \\
\hline & & & 1963 Cook et al. (67), Johnstone and Quan (171) \\
\hline & & & 1964 Elmenhorst and Reckzeh (18) \\
\hline \multirow[t]{6}{*}{76} & Naphthalene, 2-methyl- & $91-57-6$ & 1955 Cooper and Lindsey (71) \\
\hline & & & 1956 Gilbert and Lindsey (59) \\
\hline & & & 1959 Johnstone and Plimmer (63) \\
\hline & & & 1960 Rodgman and Cook (3) \\
\hline & & & $\begin{array}{l}1963 \text { Cook et al. (67), Johnstone and Quan (171), Philip Morris } \\
\text { (16) }\end{array}$ \\
\hline & & & 1964 Elmenhorst and Reckzeh (18) \\
\hline 77 & Naphthalene, 2-phenyl- & $612-94-2$ & 1960 Rodgman and Cook (3) \\
\hline \multirow[t]{2}{*}{78} & Naphthalene, 1,3,6-trimethyl- & $3031-08-1$ & 1963 Cook et al. (67), Johnstone and Quan (171) \\
\hline & & & 1964 Elmenhorst and Reckzeh (18) \\
\hline \multirow[t]{2}{*}{79} & $1 H$-Naphtho[3,2,1,8-defg]chrysene & $190-99-8$ & 1957 Wynder () \\
\hline & & & 1959 Johnstone and Plimmer (63) \\
\hline \multirow[t]{6}{*}{80} & Naphtho[2,1,8-qra]naphthacene & $196-42-9$ & 1957 Lyons and Johnston (29), Wynder and Wright (76) \\
\hline & & & 1958 Wynder et al. (77) \\
\hline & & & 1959 Johnstone and Plimmer (63), Tennessee Eastman (116) \\
\hline & & & 1960 Rodgman and Cook (3) \\
\hline & & & 1963 Philip Morris (16) \\
\hline & & & 1964 Elmenhorst and Reckzeh (18) \\
\hline \multirow[t]{4}{*}{81} & Naphtho[1,2-b]triphenylene & $215-26-9$ & 1957 Lyons and Johnston (29) \\
\hline & & & 1958 British Empire Cancer Campaign (112) \\
\hline & & & 1963 Philip Morris (16) \\
\hline & & & 1964 Elmenhorst and Reckzeh (18) \\
\hline \multirow[t]{3}{*}{82} & Pentaphene & $222-93-5$ & 1957 Wynder and Wright (76) \\
\hline & & & 1963 Philip Morris (16) \\
\hline & & & 1964 Elmenhorst and Reckzeh (18) \\
\hline
\end{tabular}




\begin{tabular}{|c|c|c|c|}
\hline No. & Polycyclic Aromatic Hydrocarbon & CAS No. & References \\
\hline \multirow[t]{9}{*}{83} & Perylene & $198-55-0$ & 1956 Gilbert and Lindsey (59), Wright and Wynder (82) \\
\hline & & & 1957 Lyons and Johnston (29) \\
\hline & & & $\begin{array}{l}1958 \text { British Empire Cancer Campaign (112), Pietzsch (84), Van } \\
\text { Duuren and Nelson (115), Wynder et al. (77) }\end{array}$ \\
\hline & & & $\begin{array}{l}1959 \text { Johnstone and Plimmer }(63) \text {, Pietzsch }(64), \text { Wynder and } \\
\text { Hoffmann }(103,110)\end{array}$ \\
\hline & & & 1960 Hoffmann and Wynder $(104,105)$, Rodgman and Cook (3) \\
\hline & & & 1960/61 Wynder (90) \\
\hline & & & 1962 Lyons (66), Pietzsch (96) \\
\hline & & & 1963 Philip Morris (16) \\
\hline & & & 1964 Elmenhorst and Reckzeh (18) \\
\hline \multirow[t]{12}{*}{84} & Phenanthrene & $85-01-8$ & 1954 Cooper and Lindsey (69) \\
\hline & & & 1955 Cooper and Lindsey (71), Lindsey (72) \\
\hline & & & $\begin{array}{l}1956 \text { Bonnet and Neukomm (58), Gilbert and Lindsey }(59,60) \text {, } \\
\text { Rodgman (1), Wright and Wynder (82) }\end{array}$ \\
\hline & & & $\begin{array}{l}1957 \text { Bonnet and Neukomm (28), Campbell and Lindsey (75), } \\
\text { Neukomm and Bonnet (108), Rand et al. (109) }\end{array}$ \\
\hline & & & $\begin{array}{l}1958 \text { Ahlmann (83), Pietzsch (84), Scassellati-Sforzolini and } \\
\text { Salucci (85), Wynder et al. (77) }\end{array}$ \\
\hline & & $85-01-8$ & 1959 Johnstone and Plimmer (63), Pietzsch (64) \\
\hline & & & 1960 Rodgman and Cook (3) \\
\hline & & & 1960/61 Wynder (90) \\
\hline & & & $\begin{array}{l}1961 \text { Scassellati-Sforzolini and Mariani (92, 93), Scassellati- } \\
\text { Sforzolini and Saldi (94) }\end{array}$ \\
\hline & & & 1962 Lyons (66), Parmele and Jensen (95), Pietzsch (96) \\
\hline & & & 1963 Cook et al. (67), Philip Morris (16) \\
\hline & & & 1964 Elmenhorst and Reckzeh (18), Kröller (101), USPHS (15) \\
\hline \multirow[t]{2}{*}{85} & Phenanthrene, dimethyl- & $29062-98-4$ & 1956 Bonnet and Neukomm (58) \\
\hline & & & 1960 Rodgman and Cook (3) \\
\hline \multirow[t]{4}{*}{86} & Phenanthrene, 2,5-dimethyl- & $3674-66-6$ & 1958 Ahlmann (83) \\
\hline & & & 1959 Johnstone and Plimmer (63) \\
\hline & & & 1963 Philip Morris (16) \\
\hline & & & 1964 Elmenhorst and Reckzeh (18) \\
\hline 87 & Phenanthrene, methyl- & $31711-53-2$ & 1960 Rodgman and Cook (3) \\
\hline \multirow[t]{7}{*}{88} & Phenanthrene, 9-methyl- & $883-20-5$ & 1956 Bonnet and Neukomm (58) \\
\hline & & & 1957 Neukomm and Bonnet (108) \\
\hline & & & 1958 Ahlmann (83) \\
\hline & & & 1959 Johnstone and Plimmer (63) \\
\hline & & & 1960 Rodgman and Cook (3) \\
\hline & & & 1963 Philip Morris (16) \\
\hline & & & 1964 Elmenhorst and Reckzeh (18) \\
\hline \multirow[t]{9}{*}{89} & Pyrene & $129-00-0$ & 1953 Cooper and Lindsey (68) \\
\hline & & & 1954 Commins et al. (80), Cooper and Lindsey (69) \\
\hline & & & $\begin{array}{l}1955 \text { Cooper and Lindsey (71), Lettré and Jahn (107), Lindsey } \\
\text { (72), Lyons (73) }\end{array}$ \\
\hline & & & $\begin{array}{l}1956 \text { Bonnet and Neukomm (58), Campbell and Lindsey (74), } \\
\text { Gilbert and Lindsey (60), Rodgman (1), Wright and } \\
\text { Wynder (82), Wynder and Wright (130) }\end{array}$ \\
\hline & & & $\begin{array}{l}1957 \text { Bonnet and Neukomm (28), Campbell and Lindsey (75), } \\
\text { Lyons and Johnston (29), Neukomm and Bonnet (108), } \\
\text { Rand et al. (109), Wynder and Wright (76) }\end{array}$ \\
\hline & & & $\begin{array}{l}1958 \text { Ahlmann (83), Orris et al. (10), Pietzsch (84), Van Duuren } \\
(114,120,140), \text { Van Duuren and Nelson (115), Wynder } \\
\text { et al. (77) }\end{array}$ \\
\hline & & & $\begin{array}{l}1959 \text { Bonnet and Neukomm }(61,62) \text {, Johnstone and Plimmer } \\
\text { (63), Lindsey }(78,86) \text {, Lindsey et al. (144), Pietzsch (64), } \\
\text { Wynder and Hoffmann }(103,110)\end{array}$ \\
\hline & & & $\begin{array}{l}1960 \text { Candeli et al. (87), Cuzin (88), Hoffmann and Wynder } \\
(104,105), \text { Mouron et al. (89), Rodgman and Cook (3), } \\
\text { Takayama and Oota (155) }\end{array}$ \\
\hline & & & 1960/61 Wynder (90) \\
\hline
\end{tabular}


Table 4. (cont.)

\begin{tabular}{|c|c|c|c|}
\hline No. & Polycyclic Aromatic Hydrocarbon & CAS No. & References \\
\hline \multirow[t]{4}{*}{89} & Pyrene (cont.) & $129-00-0$ & $\begin{array}{l}1961 \text { Mouron et al. (158), Sasmoco (91), Scassellati-Sforzolini } \\
\text { and Mariani (92, 93), Scassellati-Sforzolini and Saldi (94) }\end{array}$ \\
\hline & & & 1962 Lyons (66), Parmele and Jensen (95), Pietzsch (96) \\
\hline & & & 1963 Cuzin et al. (97), Philip Morris (16) \\
\hline & & & 1964 USPHS (15) \\
\hline \multirow[t]{5}{*}{90} & Pyrene, alkyl- & & 1959 Wynder and Hoffmann $(103,110)$ \\
\hline & & & 1960 Hoffmann and Wynder $(104,105)$ \\
\hline & & & 1960/61 Wynder (90) \\
\hline & & & 1962 Lyons (66), Parmele and Jensen (95) \\
\hline & & & 1963 Philip Morris (16) \\
\hline \multirow[t]{2}{*}{91} & Pyrene, ethyl- & & 1955/56 Falk and Kotin (124) \\
\hline & & & 1963 Philip Morris (16) \\
\hline 92 & Pyrene, methyl- & $27577-90-8$ & $\begin{array}{l}1958 \text { Ahlmann (83), Van Duuren }(120,140) \text {, Van Duuren and } \\
\text { Nelson (115) }\end{array}$ \\
\hline \multirow[t]{6}{*}{93} & Pyrene, 1-methyl- & 2381-21-7 & 1955 Cooper and Lindsey (71) \\
\hline & & & 1956 Bonnet and Neukomm (58), Gilbert and Lindsey $(59,60)$ \\
\hline & & & 1959 Johnstone and Plimmer (63) \\
\hline & & & 1960 Rodgman and Cook (3) \\
\hline & & & 1963 Philip Morris (16) \\
\hline & & & 1964 Elmenhorst and Reckzeh (18) \\
\hline \multirow[t]{6}{*}{94} & Pyrene, 2-methyl- & $3442-78-2$ & 1956 Bonnet and Neukomm (58), Rodgman (1) \\
\hline & & & 1958 Van Duuren (120), Wynder et al. (77) \\
\hline & & & 1959 Johnstone and Plimmer (63) \\
\hline & & & 1960 Rodgman and Cook (3) \\
\hline & & & 1963 Philip Morris (16) \\
\hline & & & 1964 Elmenhorst and Reckzeh (18) \\
\hline \multirow[t]{6}{*}{95} & Pyrene, 4-methyl- & $3353-12-6$ & 1956 Bonnet and Neukomm (58) \\
\hline & & & $\begin{array}{l}1958 \text { Van Duuren }(114,120,140), \text { Van Duuren and Nelson } \\
\text { (115) }\end{array}$ \\
\hline & & & 1959 Johnstone and Plimmer (63) \\
\hline & & & 1960 Hoffmann and Wynder (105), Rodgman and Cook (3) \\
\hline & & & 1963 Philip Morris (16) \\
\hline & & & 1964 Elmenhorst and Reckzeh (18) \\
\hline 96 & Rubicene & $197-61-5$ & 1961 Izawa (169) \\
\hline 97 & Triphenylene & $217-59-4$ & 1961 Izawa (169) \\
\hline
\end{tabular}

${ }^{a}$ By January 1964, the date of the report of the Advisory Committee to the Surgeon General, of approximately 2100 PAHs bioassayed in laboratory animals, $480(22.9 \%)$ were found to be tumorigenic to some degree.

${ }^{\mathrm{d}} \mathrm{PAH}$ was discussed by the Advisory Committee (15) as a carbon black component not a cigarette MSS component.

${ }^{\mathrm{e}}$ The PAH originally defined as cholanthrene (1,2-dihydrobenz[]]aceanthrylene) by RODGMAN and COOK (3) may have been one of several benzocyclopentanthracenes later reported by SNOOK et al. who identified over 500 PAHs in MSS (18). However, SNOOK et al. did not identify cholanthrene in cigarette MSS (19). In subsequent listings, the listing of benzocyclopentanthracenes replaced the original listing of 1,2-dihydrobenz[]]aceanthrylene (cholanthrene) as a tobacco smoke component

${ }^{f}$ The PAH known as benz[e]acephenanthrylene was formerly known as benzo[b]fluoranthene.

${ }^{9}$ The PAH originally identified in cigarette MSS by WYNDER and WRIGHT (31), LYONS and JOHNSTON (29), LYONS (30), BONNET and NEUKOMm (28), RODGMAN (2), RODGMAN and COOK (3), and PYRIKI (32) as dibenzo[a,/]pyrene

\{dibenzo[def,p]chrysene\} on the basis of published UV spectral data was subsequently shown by LAVIT-LAMY and BUUHoï (33) to be dibenz[a,e]aceanthrylene. The authentic dibenzo[a,]pyrene \{dibenzo[def,p]chrysene\} was subsequently identified in MS by SNOOK et al. (19) at the USDA.

${ }^{h}$ The PAH known as $11 H$-indeno[2,1-a]phenanthrene was formerly known as $11 \mathrm{H}$-naphtho[2,1-a]fluorene.

8. Kosak, A.I., J.S. Swinehart, and D. Taber: The components of cigarette smoke. I. Preliminary studies; J. Nat. Cancer Inst. 17 (1956) 375-390.

9. Fieser, L.F.: Chemical carcinogenesis; Arthur Stolle Festschrift (1957) 489-498.

10. Orris L., B.L. Van Duuren, A.I. Kosak, N. Nelson, and F.L. Schmitt: The carcinogenicity for mouse skin and the aromatic hydrocarbon content of cigarette-smoke condensate; J. Natl. Cancer Inst. 21 (1958) 557-561.
11. Fieser, L.F.: More on smoking and health; Chemistry 1964(3) 18-19.

12. Wynder, E.L. and D. Hoffmann: Experimental tobacco carcinogenesis; Adv. Cancer Res. 8 (1964) 249-453.

13. Wynder, E.L. and D. Hoffmann: Tobacco and tobacco smoke: Studies in experimental carcinogenesis; Academic Press, New York, NY (1967).

14. Wynder, E.L. and D. Hoffmann: The role of higher polycyclic hydrocarbons in tobacco carcinogenesis; 
Proc. Am. Assoc. Cancer Res. 3 (1) (1959) 74; A study of tobacco carcinogenesis. VII. The role of higher polycyclic hydrocarbons; Cancer 12 (1959) 1079-1086.

15. United States Public Health Service (USPHS): Smoking and health: Report of the Advisory Committee to the Surgeon General of the Public Health Service; PHS Publ. No. 1103 (1964).

16. Philip Morris Inc.: Chemical constituents in tobacco and smoke. A compilation of published information; Philip Morris Inc., Richmond, VA (1963) pp. 1-47.

17. Rodgman, A.: The analysis of cigarette smoke condensate. XXXV. A summary of an eight-year study; RDR, 1964, No. 10, February 12, see www.rjrtdocs.com 501008855 -8928.

18. Elmenhorst, H. and G. Reckzeh: Aromatische Kohlenwasserstoffe im Tabakrauch [Aromatic hydrocarbons in tobacco smoke]; Beitr. Tabakforsch. 2 (1964) 180-204.

19. Snook, M.E., R.F. Severson, R.F. Arrendale, H.C. Higman, and O.T. Chortyk: High molecular weight polynuclear aromatic hydrocarbons of cigarette smoke; $29^{\text {th }}$ Tobacco Chemists' Research Conference, Program Booklet and Abstracts, Vol. 29, Paper No. 21, 1975, p. 19; The identification of high molecular weight polynuclear aromatic hydrocarbons in a biologically active fraction of cigarette smoke condensate; Beitr. Tabakforsch. Int. 9 (1977) 79-101; Multi-alkylated polynuclear aromatic hydrocarbons of tobacco smoke: Separation and identification; Beitr. Tabakforsch. Int. 9 (1978) 222-247; Snook, M.E., R.F. Severson, H.C. Higman, R.F. Arrendale, and O.T. Chortyk: Polynuclear aromatic hydrocarbons of tobacco smoke: Isolation and identification; Beitr. Tabakforsch. 8 (1976) 250-272; Snook, M.E., R.F. Severson, H.C. Higman, and O.T. Chortyk: Isolation and identification of polynuclear aromatic hydrocarbons of tobacco smoke; $28^{\text {th }}$ Tobacco Chemists' Research Conference, Program Booklet and Abstracts, Vol. 28, Paper No. 40, 1974, p. 27.

20. Rodgman, A. and T.A. Perfetti: The composition of cigarette smoke: A catalogue of the polycyclic aromatic hydrocarbons; Beitr. Tabakforsch. Int. 22 (2006) 13-69.

21. Cook, J.W., C.L. Hewitt, and I. Hieger: Coal-tar constituents and cancer; Nature 130 (1932) 926; Isolation of a cancer-producing hydrocarbon from coal tar. II. Isolation of 1,2- and 4,5-benzpyrenes, perylene, and 1,2-benzanthracene; J. Chem. Soc. (1933) 395-398.

22. Orchin, M. and E.O. Woolfolk: Molecular complexes with 2,4,7-trinitrofluorenone; J. Am. Chem. Soc. 68 (1946) 1727-1729; Orchin, M., L. Reggel, and E.O. Woolfolk: Molecular complexes with 2,4,7trinitrofluorenone. II; J. Am. Chem. Soc. 69 (1947) 1225-1227.

23. Wynder, E.L., E.A. Graham, and A.B. Croninger: Experimental production of carcinoma with cigarette tar; Cancer Res. 13 (1953) 855-864.

24. Bradford, J.A., W.R. Harlan, and H.R. Hanmer: Nature of cigaret smoke: Technic of experimental smoking; Ind. Eng. Chem. 28 (1936) 836-839.

25. Hartwell, J.L.: Survey of compounds which have been tested for carcinogenic activity; United States Public Health Service (USPHS) Publ. No. 149, (1947) Washington, DC; Survey of compounds which have been tested for carcinogenic activity; United States
Public Health Service (USPHS) Publ. No. 149, $2^{\text {nd }}$ Edition (1951), Washington, DC; Shubik, P. and J.L. Hartwell: Survey of compounds which have been tested for carcinogenic activity, Suppl. 1; United States Public Health Service (USPHS) Publ. No. 149 (1957) Washington, DC; Suppl. 2; USPHS Publ. No. 149 (1969) Washington, DC.

26. Dipple, A., R.C. Moschel, and C.A.H. Bigger: Polynuclear hydrocarbons. Chapter 2 in Chemical carcinogens, Second edition; edited by C.E. Searle, Am. Chem. Soc. Monograph 182, American Chemical Society, Washington, DC (1984) 41-163.

27. Sander, L.C. and S.A. Wise: Polycyclic aromatic hydrocarbon structure index; National Institute of Standards and Technology Special Publication 922 (1997).

28. Bonnet, J. and S. Neukomm: Résultats actuels des recherches chimiques sur la composition de la fumée du tabac [Current results on the chemical research on the composition of tobacco smoke]; Oncologia 10 (1957) 124-129.

29. Lyons, M.J. and H. Johnston: Chemical analysis of the neutral fraction of cigarettes smoke tar; Brit. J. Cancer 11 (1957) 554-562.

30. Lyons, M.J.: Presence of 1,2,3,4-dibenzpyrene in cigarette smoke; Nature 182 (1958) 178.

31. Wynder, E.L. and G.F Wright: Studies on the identification of carcinogens in cigarette tar; Proc. Am. Assoc. Cancer Res. 2 (2) (1956) 159; A study of tobacco carcinogenesis. I. The primary fractions; Cancer 10 (1957) 255-271.

32. Pyriki, C.: Polycyclische und aliphatische Kohlenwasserstoffe des Tabakrauches [Polycyclic and aliphatic hydrocarbons in tobacco smoke]; German Chem. Soc., Ann. Mtg., Leipzig DDR (1962); Die Nahrung 7 (1963) 439-448.

33. Lavit-Lamy, D. and N.P. Buu-Hoï: The true nature of "dibenzo[a,l]pyrene" and its known derivatives; Chem. Comm. 4 (1966) 92-94.

34. Rodgman, A. and L.C. Cook: The composition of cigarette smoke. I. Solanesyl acetate; Tob. Sci. 3 (1959) 86-88.

35. Rodgman, A.: The composition of cigarette smoke. III. Phytadienes; J. Org. Chem. 24 (1959) 1916-1924.

36. Rodgman, A., L.C. Cook, and S.S. Mims: The composition of cigarette smoke. V. Solanesenes; $14^{\text {th }}$ Tobacco Chemists' Research Conference, Program Booklet and Abstracts, Vol. 14, Paper No. 23, 1960, pp. 12-13; J. Org. Chem. 26 (1961) 497-501.

37. Friedel, R.A. and M. Orchin: Ultraviolet spectra of aromatic compounds; John Wiley and Sons, Inc., New York, NY (1961).

38. Hofer, L.J.E. and W.C. Peebles: X-ray diffraction patters of 2,4,7-trinitrofluorenone derivatives of aromatic hydrocarbons; Anal.. Chem. 24 (1952) 822-826.

39. Soffer, M.D. and R.A. Stewart: The purification and identification of 1-methylnaphthalene; J. Am. Chem. Soc. 74 (1952) 567-568.

40. Shriner, R.L. and R.C. Fuson: The systematic identification of organic compounds: A laboratory manual; $3^{\text {rd }}$ Edition, John Wiley and Sons, New York, 
NY (1948) p. 259.

41. Fieser, L.F.: Experiments in organic chemistry; $2^{\text {nd }}$ Edition, D.C. Heath and Co., New York, NY (1941) p. 344.

42. Clar, E.: Aromatische Kohlenwasserstoffe: Polycyclische Systeme [Aromatic hydrocarbons: Polycyclic systems]; Springer-Verlag, Berlin, Germany (1952).

43. Ikeda, S.: Contribution to the study of tobacco smoke; Sci. Papers, Inst. Phys. Chem. Res. (Tokyo) 42 (1947) 80.

44. Roffo, A.E.: Espectrograffe de los derivados obtenidos por destilacion directa de los tabacos y su relacion como agentes carcinogenos [Spectrograph of derivatives obtained by direct distillation of tobaccos and the relation to carcinogenic agents]; Bol. Inst. Med. Exptl. Estud. Cáncer 14 (1937) 311-399, see Chem. Abstr. 32 (1938) $3812^{3}$; Espectrograffe de los derivados obtenidos por destilacion directa de los tabacos y su relacion como agentes carcinogenos [Spectrograph of derivatives obtained by direct distillation of tobaccos and the relation to carcinogenic agents]; Bol. Inst. Med. Exptl. Estud. Cáncer 17 (1940) 279.

45. Roffo, A.H.: 1,2-Benzopirene: Cancerigeno extraido del alquitran del tabaco [1,2-Benzpyrene: A carcinogen extracted from tobacco tar]; Bol. Inst. Med. Exp. Estud. Cáncer 16 (1939) 1-38; Krebserzeugendes Benzpyren gewonnen aus Tabakteer [Cancer-causing benzpyrene obtained from tobacco tar]; Z. Krebsforsch. 49 (1939) 588-597, see Biol. Abstr. 14 (1939) 16122.

46. Larson, P.S., H.B. Haag, and H. Silvette: Tobacco: Experimental and clinical studies; Williams and Wilkins Company, Baltimore, MD (1961) pp. 422-424.

47. Rodgman, A. and T.A. Perfetti: The chemical components identified in tobacco and tobacco smoke prior to 1954: A chronology of classical chemistry; Beitr. Tabakforsch. Int. 23 (2009) 277-333.

48. Wynder, E.L. and E.A. Graham: Tobacco smoking as a possible etiologic factor in bronchiogenic carcinoma: A study of 684 cases; J. Am. Med. Assoc. 143 (1950) 329-336; Doll, R. and A.B. Hill: Smoking and carcinoma of the lung. Preliminary report; Brit. Med. J. 1950 (ii) 739-748; Levin, M.L., H. Goldstein, and P.R. Gerhardt: Cancer and tobacco smoking: A preliminary report; J. Am. Med. Assoc. 143 (1950) 336-338; Mills, C.A. and M.M. Porter: Tobacco smoking habits and cancer of the mouth and respiratory system; Cancer Res. 10 (1950) 539-542; Schrek, R., L.A. Baker, G.P. Ballard, and S. Dolgoff: Tobacco smoking as an etiologic factor in disease; Cancer Res. 10 (1950) 49-58; Doll, R. and A.B. Hill: A study of the aetiology of carcinoma of the lung; Brit. Med. J. 1952(ii) 1271-1286; McConnell, B.B., K.C.T. Gordon, and T. Jones: Occupational and personal factors in the etiology of cancer of the lung; Lancet 1952(ii) 651-656; Koulumies, M.: Smoking and pulmonary carcinoma; Acta Radiol. 39 (1953) 255-260; Lickint, F.: Ätiologie und Prophylaxe des Lungenkrebses. 2. Statistische Voraussetzungen zur Klärung der Tabakrauchätiologie des Lungenkrebses [Etiology and prophylaxis of lung cancer. 2. Statistical assumptions for clarification of the tobacco smoke etiology of lung cancer]; Steinkopf
(1953); Sadowsky, D.A., A.G. Gilliam, and J. Cornfield: The statistical association between smoking and carcinoma of the lung; J. Natl. Cancer Inst. 13 (1953) 1237-1258.

49. Snook, M.E., H.C. Higman, R.F. Arrendale, and O.T. Chortyk: Isolation and identification of nitrogen analogs of polynuclear aromatic hydrocarbons; $30^{\text {th }}$ Tobacco Chemists' Research Conference, Program Booklet and Abstracts, Vol. 30, Paper No. 47, 1976, p. 32; Snook, M.E., P.J. Fortson, L.B. Smith, and O.T. Chortyk: Isolation and identification of aza-arenes of tobacco smoke; $32^{\text {nd }}$ Tobacco Chemists' Research Conference, Program Booklet and Abstracts, Vol. 32, Paper No. 46, 1978, p. 25; Snook, M.E., P.J. Fortson, and O.T. Chortyk: Isolation and identification of aza-arenes of tobacco smoke; Beitr. Tabakforsch. Int. 11 (1981) $67-78$

50. Newell, M.P., R.A. Heckman, R.F. Moates, C.R. Green, F.W. Best, and J.N Schumacher: The composition of the ether-soluble portion of the particulate phase of cigarette smoke; $29^{\text {th }}$ Tobacco Chemists' Research Conference, Program Booklet and Abstracts, Vol. 29, Paper No. 39, 1975, p. 28; Isolation and identification of new components of the ether-soluble portion of cigarette smoke condensate; Tob. Sci. 22 (1978) 6-11.

51. Schumacher, J.N., C.R. Green, and F.W. Best: The composition of the water-soluble portion of cigarette smoke particulate phase; $29^{\text {th }}$ Tobacco Chemists' Research Conference, Program Booklet and Abstracts, Vol. 29, Paper No. 38, 1975, p. 27; Schumacher, J.N., C.R. Green, F.W. Best, and M.P. Newell: Smoke composition. An extensive investigation of the water-soluble portion of cigarette smoke; J. Agr. Food Chem. 25 (1977) 310-320.

52. Heckman, R.A. and F.W. Best: An investigation of the lipophilic bases of cigarette smoke condensate; $32^{\text {nd }}$ Tobacco Chemists' Research Conference, Program Booklet and Abstracts, Vol. 32, Paper No. 47, 1978, p. 25; Tob. Sci. 25 (1981) 33-39.

53. Lloyd, R.A. Jr, C.W Miller, D.L. Roberts, J.A. Giles, J.P. Dickerson, N.H. Nelson, C.E. Rix, and P.H. Ayers: Flue-cured tobacco flavor. I. Essence and essential oil components; CORESTA 1974 Symp., Montreux, Switzerland (1974); Tob. Sci. 20 (1976) 40-48.

54. Leffingwell, J.C. and E.D. Alford: Volatile constituents of Perique tobacco; Electronic J. Environ. Agr. Food Chem. 4 (2005) 899-915.

55. Peng, F., L. Sheng, B. Liu, H. Tong, and S. Liu: Comparison of different extraction methods: Steam distillation, simultaneous distillation and extraction and headspace co-distillation, used for the analysis of the volatile components in aged flue-cured tobacco leaves; J. Chromat. A 1040 (2004) 1-17.

56. Kotin, P.: Letter to E.H. Guthrie; Staff Director, 1964 Advisory Committee on Smoking and Health (September 6, 1963).

57. Kotin, P. and H.L. Falk: Atmospheric factors in pathogenesis of lung cancer; Adv. Cancer Res. 7 (1953) 475-514.

58. Bonnet, J. and S. Neukomm: Sur la composition chimique de la fumée du tabac. I. Analyse de la fraction 
neuter [On the chemical composition of tobacco smoke. I. Analysis of the neutral fraction]; Helv. Chim. Acta 39 (1956) 1724-1733.

59. Gilbert, J.A.S. and A.J. Lindsey: Polycyclic hydrocarbons in cigarette smoke: The amounts held in stubs and ash; Brit. J. Cancer 10 (1956) 642-645.

60. Gilbert, J.A.S. and A.J. Lindsey: Polycyclic hydrocarbons in tobacco smoke: Pipe smoking experiments; Brit. J. Cancer 10 (1956) 646-648.

61. Bonnet, J. and S. Neukomm: Carcinogenic and cocarcinogenic substances in tobacco smoke; Acta Unio Internat. Contra Cancrum 15 (1959) 561-563

62. Bonnet, J. and S. Neukomm: New investigations on carcinogenic substances in tobacco smoke; Oncologia 12 (1959) 80-86.

63. Johnstone, R.A.W. and J.R. Plimmer: The chemical constituents of tobacco and tobacco smoke; Chem. Rev. 59 (1959) 885-936.

64. Pietzsch, A.: Zum Nachweis von cancerogenen Kohlenwasserstoffen im Tabakrauch [On the detection of carcinogenic hydrocarbons in tobacco smoke]; Pharmazie (Berlin) 14 (1959) 466-473.

65. Zapior, B., J. Platek, and J. Kaleta: Polycyclic aromatic hydrocarbons in the smoke of domestic Polish cigarette brands; Roczniki Chemii 33 (1959) 243-245.

66. Lyons, M.J.: Comparison of aromatic polycyclic hydrocarbons from gasoline engine and diesel engine exhausts, general atmospheric dust, and cigarette smoke condensate; in: Symposium: Analysis of carcinogenic air pollutants, edited by E. Sawicki and K. Cassel, Natl. Cancer Inst. Monograph 9 (1962) 193-199.

67. Cook, J.W., R.A.W. Johnstone, and P.M. Quan: The composition of cigarette smoke. VIII. Some aromatic hydrocarbon constituents; Israel J. Chem. 1 (1963) 356-364.

68. Cooper, R.L. and A.J. Lindsey: The presence of polynuclear hydrocarbons in cigarette smoke; Chem. and Ind. (London) (1953) 1205.

69. Cooper, R.L. and A.J. Lindsey: The presence of 3,4benzpyrene and other polycyclic hydrocarbons in the combustion products of cigarette paper; Chem. and Ind. (London) (1954) 1260-1261.

70. Cooper, R.L., A.J. Lindsey, and R.E. Waller: The presence of 3,4-benzpyrene in cigarette smoke; Chem. and Ind. (London) (1954) 1418.

71. Cooper, R.L. and A.J. Lindsey: 3,4-Benzpyrene and other polycyclic hydrocarbons in cigarette smoke; Brit. J. Cancer 9 (1955) 304-309.

72. Lindsey, A.J.: The composition of tobacco smoke. Some minor organic constituents; Analyst 80 (1955) 164.

73. Lyons, M.J.: Tobacco smoke products. Assay for polycyclic hydrocarbons; Brit. Emp. Cancer Camp., Ann. Rpt. 33 (1955) 277-278.

74. Campbell, J.M. and A.J. Lindsey: Polycyclic hydrocarbons extracted from tobacco. The effect upon total quantities found in smoking; Brit. J. Cancer 10 (1956) 649-652.

75. Campbell, J.M. and A.J. Lindsey: Polycyclic hydrocarbons in cigar smoke; Brit. J. Cancer 11 (1957) 192-195.

76. Wynder, E.L. and G.F Wright: A study of tobacco carcinogenesis. I. The primary fractions; Cancer 10 (1957) 255-271.

77. Wynder, E.L., G.F Wright, and J. Lam: A study of tobacco carcinogenesis. V. The role of pyrolysis; Proc. Am. Assoc. Cancer Res. 2(4) (1958) 357-358, Cancer 11 (1958) 1140-1148.

78. Lindsey, A.J.: The composition of cigarette smoke: Studies on stubs and tips; Brit. J. Cancer 13 (1959) 195-199.

79. Alexandrov, K., P. Simova, and I. Savatinova: Potentielle kanzerogene Substanzen in Zigarettenrauch. Befund 3,4-Benzpyren [Potential carcinogenic substances in cigarette smoke. 3,4-Benzpyrene found]; Neoplasma 8 (1961) 575-576.

80. Commins, B.T., R.L. Cooper, and A.J. Lindsey: Polycyclic hydrocarbons in cigarette smoke; Brit. J. Cancer 8 (1954) 296-302.

81. Seelkopf, C.: Über die Isolierung cancerogene Stoffe aus dem Zigarettenteer [On the isolation of cancerogenic substances from cigarette tar]; Z. Lebensm. Untersuch. Forsch. 100 (1955) 218-222.

82. Wright, G.F and E.L. Wynder: Further chemical studies of cigarette smoke condensate; Proc. Am. Assoc. Cancer Res. 2(2) (1956) 159.

83. Ahlmann, J.: Detection of polycyclic aromatic hydrocarbons in cigarette tar; Acta Pathol. Microbiol. Scand. 43 (1958) 379-390.

84. Pietzsch, A.: Zum Nachweis von cancerogenen Kohlenwasserstoffen im Tabakrauch [On the detection of carcinogenic hydrocarbons in tobacco smoke]; Naturwissenschaften 45 (1958) 445.

85. Scassellati-Sforzolini, G. and G. Salucci: Prime ricerche sulla presenza di idrocarburi cancerigeni nel fumo delle sigarette Italiane [Initial research on the presence of carcinogenic hydrocarbons in the smoke of Italian cigarettes]; Boll. Soc. Ital. Biol. Sper. 34 (1958) 424-426.

86. Lindsey, A.J.: Tobacco smoke; Brit. Med. J. 1959(ii) 506.

87. Candeli, A., A.J. Lindsey, and K. Persaud: Carta di sigarette al sulfammato di ammonio e idrocarburi cancerigeni [Cigarette paper containing ammonium sulfamate and carcinogenic hydrocarbons]; Bol. Soc. Ital. Biol. Sper. 36 (1960) 452-454.

88. Cuzin, J.L.: Determination of anthracene, pyrene, and benzo $[a]$ pyrene in condensates of tobacco smoke; SEITA (January, 1960).

89. Mouron, J.C., J. Bonnet, and S. Neukomm: Extraction of tobacco by some organic solvents and consequences on chemical composition of the smoke; Oncologia 13 (1960) 271-278.

90. Wynder, E.L.: Laboratory contributions to the tobaccocancer problem; Symposium on Chemical and biological problems related to smoking, Stockholm, Sweden (1960); Acta Med. Scand. Suppl. 369 (1961) 63-101.

91. Sasmoco, S.A.: Improvements in or relating to a process for treating tobacco and tobacco obtained by said process; British Patent No. 885,249 (Cl. 130) (December 30, 1961).

92. Scassellati-Sforzolini, G. and A. Mariani: Benzopirene e di altri idrocarburi policiclici nel fumo delle sigarette "Nationale Esportazione" [Benzopyrene and other 
polycyclic hydrocarbons in the smoke of "Nationale Esportazione"]; Boll. Soc. Ital. Biol. Sper. 37 (1961) 766-768.

93. Scassellati-Sforzolini, G. and A. Mariani: Ricerca del 3:4-benzopirene e di altri idrocarburi policiclici nel fumo di sigarette Italiane: Contributo allo studio dell'azione cancerigene del fumo di tobacco [Research on 3:4-benzopyrene and other polycyclic hydrocarbons in the smoke of Italian cigarettes: Contribution to the study of the carcinogenic action of tobacco smoke]; Ricerca Sci. Rend. 1(2) (1961) 98-117.

94. Scassellati-Sforzolini, G. and G. Saldi: Ulteriori ricerche sugli idrocarburi policiclici del fumeso di sigarette. (Confronto tra il fumo aspirato e quello raccolto nell'aria ambiente) [Further research on the polycyclic hydrocarbon content of the smoke of cigarettes. (Comparison between the aspirated smoke from cigarettes and that recovered from the ambient air)]; Boll. Soc. Ital. Biol. Sper. 37 (1961) 769-771.

95. Parmele, H.B. and C.O. Jensen: Smoking tobacco product; British Patent No. 903,067 (August 9, 1962).

96. Pietzsch, A.: Ein weiterer Beitrag zum Thema Retinierung von Rauchbestandteilen beim Zigarettenrauchen [An additional contribution to the theme of retention of smoke components from cigarette smoke]; Pharmazie (Berlin) 17 (1962) 36-41.

97. Cuzin, J.L., A. Testa, S. Testa, and G. Anguerra: Chemical and biological control of condensates from smoked tobacco treated after the Neukomm-Bonnet process; Z. Präventivmed. 28 (1963) 125-137.

98. Dickey, J.B. and G.P. Touey: Tobacco research: Hydrocarbon components of the gaseous phase of cigarette smoke; Seminar presented at Research Dept., R.J. Reynolds Tobacco Company, Winston-Salem NC (March 1, 1956), edited by A. Rodgman, see www.rjrtdocs.com 503132566 -2594.

99. Tennessee Eastman Corporation: Composition of tobacco smoke; Tennessee Eastman Corp. Res. Rpt. No. 4-1201-1 (August 21, 1956).

100. Lyons, M.J.: Assay of possible carcinogenic hydrocarbons from cigarette smoke; Nature 177 (1956) 630-631.

101. Kröller, E.: Ergebnisse vergleichender Schwel- und Rauchversuche an Tabak [Comparative results of smoldering and smoking studies on tobacco]; Deut. Lebensm. Rundschau 60 (1964) 214-215.

102. Hoffmann, D. and E.L. Wynder: Identification of polynuclear aromatic hydrocarbons; $136^{\text {th }}$ Natl. Mtg., Am. Chem. Soc., Atlantic City, NJ (1959) Paper No. 16 U.

103. Wynder, E.L. and D. Hoffmann: A study of tobacco carcinogenesis. VII. The role of higher polycyclic hydrocarbons; Cancer 12 (1959) 1079-1086.

104. Hoffmann, D. and E.L. Wynder: Short-term determination of carcinogenic aromatic hydrocarbons; Anal. Chem. 32 (1960) 295-296.

105. Hoffmann, D. and E.L. Wynder: On the isolation and identification of polycyclic aromatic hydrocarbons; Cancer 13 (1960) 1062-1073.

106. Wynder, E.L. and D. Hoffmann: Present status of laboratory studies on tobacco carcinogenesis; Acta Pathol. Microbiol. Scand. 52 (1961) 119-132.

107. Lettré, H. and A. Jahn: Zur Bildung aromatischer
Kohlenwasserstoffe während des Rauchprozesses [The formation of aromatic hydrocarbons during the smoking process]; Naturwissenschaften 42 (1955) 210.

108. Neukomm, S. and J. Bonnet: Untersuchungen über cancerogene Stoffe im Tabakrauch [Investigation of carcinogenic substances in tobacco smoke]; StrahlenTherapie 37 (Suppl.) (1957) 128-132.

109. Rand, H.J., E.T. Alvord, S.Z. Cardon, and A. Burhan: A study of cigarette smoke and cigarette paper smoke alone; Am. J. Surg. 94 (1957) 438-443.

110. Wynder, E.L. and D. Hoffmann: The role of higher polycyclic hydrocarbons in tobacco carcinogenesis; Proc. Am. Assoc. Cancer Res. 3(1) (1959) 74.

111. Bonnet, J.: What carcinogenic substances have been demonstrated to be present in tobacco smoke condensate; Proc. $1^{\text {st }}$ Workshop Conf. on Lung Cancer Res. (App. A) (1958) 27-30.

112. British Empire Cancer Campaign: Aromatic polycyclic hydrocarbons in cigarette smoke; Brit. Emp. Cancer Camp., Ann. Rpt. 35 (1958) 303-305.

113. Bentley, H.R. and E.G.N. Berry: The constituents of tobacco smoke: An annotated bibliography. Research Paper No. 3; Tobacco Manufacturers' Standing Committee, London (1959).

114. Van Duuren, B.L.: The polynuclear aromatic hydrocarbons in cigarette-smoke condensate. II; J. Natl. Cancer Inst. 21 (1958) 623-630.

115. Van Duuren, B.L. and N. Nelson: The polycyclic aromatic hydrocarbons in cigarette smoke; Proc. Am. Assoc. Cancer Res. 2(4) (1958) 353.

116. Tennessee Eastman Corporation: Composition of tobacco smoke. II. Composition of tobacco extract and its pyrolysis products; Tennessee Eastman Corp. Res. Rpt. No. 4-1201-2 (April 13, 1959).

117. Mold, J.D., T.B. Walker, and L.G. Veasey: Selective separation of polycyclic aromatic compounds by countercurrent distribution with a solvent system containing tetramethyluric acid; Anal. Chem. 35 (1963) 2071-2074.

118. Neukomm, S.: The newt test in relation to investigations on carcinogenic substances; in: Symposium: Analysis of carcinogenic air pollutants, edited by E. Sawicki and K. Cassels Jr, J. Natl. Cancer Inst. Monograph 9 (1962) 71-73.

119. Gil-Av, E. and J. Shabtai: Precursors of carcinogenic hydrocarbons in tobacco smoke; Nature 197 (1963) 1065-1066.

120. Van Duuren, B.L.: Identification of some polynuclear aromatic hydrocarbons in cigarette-smoke condensate; J. Natl. Cancer Inst. 21 (1958) 1-16.

121. Wieske, R.: Zur Beurteilung von Filterzigaretten [On the evaluation of filter cigarettes]; Z. Lebensm. Untersuch. Forsch. 102 (1955) 123-127.

122. Wright, G.F and E.L. Wynder: Fractionation of cigarette tar; Proc. Am. Assoc. Cancer Res. 2(1) (1955) 55.

123. Alvord, E.T. and S.Z. Cardon: Inhibition of the formation of 3,4-benzpyrene from cigarette paper smoke; Ann. Mtg., Am. Assoc. Adv. Sci., Atlanta GA (1955); The inhibition of the formation of 3,4benzpyrene in cigarette smoke; Brit. J. Cancer 10 (1956) 498-503. 
124. Falk, H.L. and P. Kotin: The experimental production of hydrocarbons in simulated cigarette smoking: Their analysis and quantitation; Progress Report No. 1, December 14, 1955, see http://legacy.library. ucsf.edu/tid/xxt6aa00; Falk, H.L.: The experimental production of hydrocarbons in simulated cigarette smoking: Their analysis and quantitation; Progress Report No. 2, February 1-November 20, 1956, see http://legacy.library.ucsf. edu/tid/uxt6aa00.

125. Babin, J., D. Polic, and B. Neskovic: Detection of carcinogenic substances in wide use. I. The amount of 3,4-benzpyrene in the smoke of "Morava" cigarettes; Glasnik 14 (4) (1956) 45-52.

126. Cardon, S.Z., E.T. Alvord, W.J. Rand, and R. Hitchcock: 3,4-Benzpyrene in the smoke of cigarette paper, tobacco, and cigarettes; Brit. J. Cancer 10 (1956) 485-497.

127. Kuratsune, M.: Benzo[a]pyrene content of certain pyrogenic materials; J. Natl. Cancer Inst. 16 (1956) 1485-1496.

128. Lam, J.: Determination of 3,4-benzopyrene and other aromatic hydrocarbons formed by pyrolysis of aliphatic tobacco hydrocarbons; Acta Path. Microbiol. Scand. 39 (1956) 207-210.

129. Lettré, H., A. Jahn, and C. Hausbeck: Nachweis von 3,4-Benzpyrene unter den Rauchprodukten [Detection of 3,4-benzpyrene in smoke products]; Angew. Chem. 68 (1956) 212-213.

130. Wynder, E.L. and G.F Wright: Studies on the identification of carcinogens in cigarette tar; Proc. Am. Assoc. Cancer Res. 2(2) (1956) 159.

131. Wright, G.F: Studies with tobacco smoke condensate; in: Proc. $3^{\text {rd }}$ Natl. Cancer Conf., June, 1956, JB Lippincott Company (1957) 479-484.

132. Neukomm, S.: Experimental studies on the carcinogenic power of tobacco smoke and other contaminants of the atmosphere; Oncologia 10 (1957) 137-155.

133. Wieske, R.: Untersuchungen über cancerogene Bestandteile im Tabakrauch [Investigations of the carcinogenic components in tobacco smoke]; Arzneimittelforschung 7 (1957) 324-329.

134. Bentley, H.R. and J.G. Burgan: Benzopyrene in tobacco and tobacco smoke; $12^{\text {th }}$ Tobacco Chemists' Research Conference, Program Booklet and Abstracts, Vol. 12, Paper No. 16, 1958, pp. 6-7; .Polynuclear hydrocarbons in tobacco and tobacco smoke. I. 3,4-Benzpyrene; Analyst 83 (1958) 442-447.

135. Cardon, S.Z.: 3,4-Benzpyrene in cigarette smoke; Tob. Sci. 2 (1958) 130-131.

136. Clemo, G.R.: Some aspects of the chemistry of tobacco smoke. I; Tetrahedron 3 (1958) 168-174.

137. Cuzin, J.L.: What is evidence for the presence of significant amounts of carcinogens in cigarette paper? In cigarette tobacco? In cigarette additives? Proc. $1^{\text {st }}$ Conf. Lung Cancer Res. (1958) 49-50.

138. Hubert-Habart, M., R. Latarjet, D. Lavalette, B. Muel, L. René, and R. Royer: Comparaison des quantités de benzo-3,4 pyrène formées par combustion de divers types de papiers à cigarettes [Comparison of the quantities of 3,4-benzpyrene formed by the combustion of different types of cigarette papers]; Bull. Cancer 53
(1958) 53-56.

139. Latarjet, R., J.L. Cuzin, M. Hubert-Habart, B. Muel, and R. Royer: Détection quantitative du 3,4 benzopyrène formé par combustion du papier à cigarettes et du tabac [Quantitative detection of 3,4-benzpyrene formed by the combustion of cigarette paper and tobacco]; Bull. Assoc. France Étude Cancer 43 (1956) 180-198.

140. Van Duuren, B.L.: The polynuclear hydrocarbons in cigarette smoke condensate; Proc. $1^{\text {st }}$ Workshop Conf. on Lung Cancer Research (1958) 52-55.

141. Burgan, J.G.: The manufacturers' contribution to experimental research on smoking and lung cancer; Trans. Assoc. Ind. Med. Officers 9 (1959) 13-17.

142. Dikun, P.P.: Use of the fine structure of the fluorescence spectrum of 3:4-benzpyrene to increase the certainty of its detection; Voprosy Onkol. 5 (12) (1959) 672-677.

143. Dikun, P.P. and S.G. Chushkin: Fluorescence spectral analysis of the products of tobacco smoke; Voprosy Onkol. 5(7) (1959) 34-37.

144. Lindsey, A.J., K. Persaud, and A. Candeli: Reduction of benzpyrene in tobacco smoke; Brit. Med. J. 1959(ii) 821.

145. Tennessee Eastman Corporation: Composition of tobacco smoke. III. Effects of the extraction of tobacco on amount of benzo $[a]$ pyrene in cigarette smoke tar; Tennessee Eastman Corp. Res. Rpt. No. 4-1201-3 (July 14, 1959).

146. Wynder, E.L., G.F Wright, and J. Lam: A study of tobacco carcinogenesis. VI. The role of precursors; Cancer 12 (1959) 1073-1078.

147. Bentley, H.R. and J.G. Burgan: Polynuclear hydrocarbons in tobacco and tobacco smoke. II. The origin of 3,4-benzpyrene found in tobacco and tobacco smoke; Analyst 85 (1960) 723-727.

148. Bentley, H.R. and J.G. Burgan: Polynuclear hydrocarbons in tobacco and tobacco smoke. III. The inhibition of the formation of 3,4-benzpyrene in cigarette smoke; Analyst 85 (1960) 727-730.

149. Candeli, A., A.J. Lindsey, and K. Persaud: Determination of polycyclic aromatic hydrocarbons in tobacco smoke; Anal. Chim. Acta 22 (1960) 458-461.

150. Clemo, G.R.: Further aspects of the chemistry of tobacco smoke. II; Tetrahedron 11 (1960) 11-14.

151. Cuzin, J.L., M. Hubert-Habart, B. Muel, R. Roger, and R. Latarjet: La production du benzo-3,4-pyrene dans des cigarettes à papier imprégné de sulfamate d'ammonium [The production of 3,4-benzopyrene in cigarettes with paper impregnated with ammonium sulfamate]; Bull. Soc. Chim. France (1960) 982.

152. Dikun, P.P., S.G. Chushkin, A.L. Gritsiute, and A.L. Mironova: The results of studies on the possible carcinogenic effect of tobacco products; Voprosy Onkol. 6 (1960) 603-604.

153. Hubert-Habart, M.R.: Le benzo-3,4 pyrène pyroformé dans les produits de combustion de la cigarette: Détection, dosage, recherche des facteurs d'inhibition [Pyrogenesis of 3,4-benzpyrene in the products from cigarette combustion: Detection, yield, research on inhibition factors]; Thesis, University of Paris (1960).

154. Pavlu, J. and J. Sula: Detection and estimation of 3,4- 
benzpyrene and arsenic in cigarette smoke; Casopis Lekaru Ceskych 96 (1960) 101-104, for translation see www.rjrtdocs.com $503288286-8293$.

155. Takayama, S. and K. Oota: Chemical analysis of cigarette tar produced by human smoking; Gann 51 (1960) 97-103.

156. Grimmer, G.: Eine Methode zur Bestimmung von 3,4Benzpyrene in Tabakrauchkondensaten [A method for the estimation of 3,4-benzpyrene in tobacco smoke condensate]; Beitr. Tabakforsch. 1 (1961) 107-116.

157. Guérin, M.: Étude sur la pouvoir cocarcinogène du goudron de fumée de cigarette [Study of the cocarcinogenic property of tar from cigarette smoke]; Bull. Assoc. Franc. Étude Cancer 48 (1961) 365-376.

158. Mouron, J.C., J. Bonnet, and S. Neukomm: Variations de la composition chimique de la fumée du tabac par l'addition de produites purs à du tabac complètement extrait [Variations in the chemical composition of the smoke from tobacco by addition of pure products to completely extracted tobacco]; Bull. Soc. Vaudoise Sci. Nat. 67 (1961) 447-453.

159. Rand, H.J., S.Z. Cardon, E.T. Alvord, and A. Burhan: A study of cigarette smoke and cigarette paper smoke alone; Cancer Cytol. 4 (1961) 18-21.

160. Barkemeyer, H.: Eine neue Methode zur Bestimmung des 3,4-Benzpyrens in Tabakrauchkondensaten [A new method for the determination of 3,4-benzpyrene in tobacco smoke condensate]; Beitr. Tabakforsch. 1 (1962) 325-328.

161. Bell, J.H.: Determination of benzo $[a]$ pyrene in cigarette smoke condensate; Report, August 30, 1962, see www.Lorillarddocs.com 00118749 -8752.

162. Bentley, H.R.: A study of carcinogenic components in tobacco smoke; Brit. Emp. Cancer Camp., Ann. Rpt. 39 (1962) 25.

163. Dikun, P.P., N.D. Krasnitskaya, and S.G. Chushkin: Some data on the content of 3,4-benzpyrene in tobacco smoke; Voprosy Onkol. 8 (1962) 31-35.

164. Druckrey, H. and A. Schildbach: Quantitativen Untersuchungen zur Bedeutung des Benzpyrens für die carcinogene Wirkung von Tabakrauch [Quantitative investigation of the significance of benzpyrene in the carcinogenic action of tobacco smoke]; Z. Krebsforsch. 65 (1963) 465-470.
165. Hoffmann, D., G. Rathkamp, and E.L. Wynder: Comparison of the yields of several selected components in the smoke from different tobacco products; J. Natl. Cancer Inst. 31 (1963) 627-637.

166. Scherbak, M.P., R.L. Rice, and J.E. de Souza: An absolute method for the determination of 3,4-benzpyrene in cigarette smoke; $17^{\text {th }}$ Tobacco Chemists' Research Conference, Program Booklet and Abstracts, Vol. 17, Paper No. 20, 1963, pp. 15-16.

167. Testa, A., P. Testa, and J.L. Cuzin: A rapid analytical technique for routine determination of benzo $[a]$ pyrene in cigarette smoke condensate; $17^{\text {th }}$ Tobacco Chemists' Research Conference, Program Booklet and Abstracts, Vol. 17, Paper No. 19, 1963, p. 15.

168. Waltz, P. and M. Häusermann: Sur un traitement du tabac en vue de diminuer la teneur en hydrocarbures policycliques de la fumée [On the treatment of tobacco to diminish the level of polycyclic hydrocarbons in its smoke]; Z. Präventivmed. 8 (1963) 111-124.

169. Izawa, M.: Review of studies of tobacco smoke; Nippon Senbai Kosha (1961).

170. Schoental, R.: Carcinogenic activity of 3,4,9,10dibenzpyrene; Acta Unio Internat. Contra Cancrum 15 (1959) 216-219.

171. Johnstone, R.A.W. and P.M. Quan: Naphthalenes in cigarette smoke; Nature 199 (1963) 1184.

172. Wynder, E.L.: Statement on the lung cancer-cigarette smoking controversy: Chemical fractionation of cigarette smoke; in: False and misleading advertising (Filter-tip cigarettes), Hearing before Subcommittee of the Committee on Government Operations (the Blatnik Hearings on Filtered Cigarettes), House of Representatives, $85^{\text {th }}$ Congress, $1^{\text {st }}$ Session (1957) 63-114, see $p$. 104.

Address for correspondence:

Alan Rodgman

2828 Birchwood Drive

Winston-Salem, North Carolina

27103-3410

USA

E-mail:arodgman@triad.rr.com 